Research Article

\title{
Analysis of the Negative Relationship between Blockchain Application and Corporate Performance
}

\author{
Rensi Li $\mathbb{D D}^{1}$ and Yinglin Wan ${ }^{2}$ \\ ${ }^{1}$ School of Accounting, Tianjin University of Commerce, Tianjin 300134, China \\ ${ }^{2}$ School of Economics and Management, Tsinghua University, Beijing 100084, China \\ Correspondence should be addressed to Rensi Li; 920162699@tjcu.edu.cn
}

Received 1 April 2021; Accepted 28 April 2021; Published 18 May 2021

Academic Editor: Fazlullah Khan

Copyright (c) 2021 Rensi Li and Yinglin Wan. This is an open access article distributed under the Creative Commons Attribution License, which permits unrestricted use, distribution, and reproduction in any medium, provided the original work is properly cited.

\begin{abstract}
Blockchain technology is one of the most critical emerging technologies. Countries are promoting the development of blockchain technology vigorously. Theoretically, blockchain technology improves the trust between enterprises, reduces information asymmetry, and promotes efficiency. It should promote corporate performance, but analyzing the actual data of Chinese listed companies, contrary to expectation, blockchain technology makes corporate performance decline. We found that this is mainly due to the effect of adverse selection through analysis and empirical tests. The enterprises that use blockchain technology are not accompanied by the increase in R\&D expenditure, investment expenditure, and patents. The companies' abnormal stock return and stock turnover rate have increased. The enterprises with worse performance are more likely to use blockchain to the hype. They can gain a short-term stock return. However, in the long run, the market-to-book ratio of government subsidies and the growth rate of corporate income are declining. Furthermore, the financial constraints are not alleviated as adverse selection only plays a role in the short term. Besides, the heterogeneity tests find that from the prospects of internal governance environment, the higher proportion of the largest shareholder, the better earning quality of the company. The enterprises with state-owned property rights have lower motivations of using blockchain to make an adverse selection. The study also found that the external environment prospects of enterprises with a lower degree of marketization and law environment are more likely to use the blockchain.
\end{abstract}

\section{Introduction}

The Internet has changed our society and life significantly; however, digital transformation has not stopped. Although the Internet has realized the data interconnection, the data reliability cannot be guaranteed. The blockchain is a new technology, it can improve trust between companies and reduce information asymmetry using distributed bookkeeping techniques, which can improve efficiency and reduce costs [1]. China emphasizes using blockchain as a significant national development strategy, takes the blockchain as a significant breakthrough in independent innovation of core technologies, and speeds up technological and industrial innovation. Many cities also introduce relevant policies to promote blockchain development, which has given birth to some advanced blockchain enterprises and applications. The development of blockchain can greatly promote the efficiency of human activities.

Satoshi Nakamoto first proposed the concept of blockchain in 2008. He invented Bitcoin [2], while different types of research on the blockchain began in 2015. At the same time, the focus of scholars shifted from Bitcoin to the underlying blockchain technology gradually. It explored how to use blockchain technology in the field of production and social operations. Blockchain is defined as a digital, decentralized, and distributed ledger in which transaction records are added in chronological order, aiming at creating a permanent and tamper-resistant record [3]. The blockchain has the characteristics of the decentralized structure, encryption system, and consistency mechanism. All participants in the blockchain can get the same data in the peer-to-peer network [4]. The data cannot be changed easily, and falsification will cause 
subsequent changes in all following items [5]. The blockchain achieves distributed consensus employing workload proof or equity proof [6]. Blockchain encodes events as blocks according to encryption rules and arranges them chronologically using consensus mechanisms to ensure integrity and consistency [7]. Blockchain includes the public chain and alliance chain, and any Internet user can access the private chain, the data of the public chain. Only a limited number of authorized participants can access the data in the alliance chain and private chain. Therefore, the alliance chain is more widely used in the business environment [8]. The smart contract is an essential application of blockchain. It can automatically implement the contract by writing the contract terms into the code in advance, avoiding default or dispute, and promoting trust between enterprises and strangers.

Previous research studies on blockchain mainly focus on how the blockchain is applied in various industries. Scholars have studied the use of blockchain in areas of supply chain management, accounting, auditing, medicine, finance, construction engineering, tourism, and others, and blockchain can be used to achieve breakthrough development in these industries [9-14]. The blockchain can increase the flexibility and resilience of supply chains, increase transparency and sustainability, improve information sharing among enterprises, and avoid fraud and data tampering [15-17]. The main applications of blockchain technology in enterprises include supply chain tracking [18], intelligent transportation systems [19], ensuring product safety, smart contract [20], product traceability [21], digitization [22], information sharing [23], increasing supply chain flexibility [24], optimizing accounting bookkeeping methods [25], improving financial forecasting [26], and sustainable performance $[27,28]$.

However, there are relatively few empirical studies on the blockchain, mainly because blockchain is still at the exploratory stage. There are relatively few enterprises implementing blockchain. A small number of scholars use the data of the United States, China, and India for empirical research. Jain and Jain [29] found that companies add blockchain fields to their names to earn abnormal stock returns. However, such abnormal stock returns can only last for 2 months and turn negative after 5 months. Sheel and Nath [30] used survey data of Indian enterprises and found that blockchain can improve the adaptability, consistency, and agility of supply chain, generate trust among enterprises, and improve corporate performance. Hoxha and Sadiku [31] examined the willingness to use blockchain technology in real estate trading systems based on questionnaire data in Kosovo. They found that it was mainly affected by transparency, cost, and transaction security. Pan et al. [32] found that blockchain can improve the operating efficiency of enterprises, increase the asset turnover rate, and reduce the ratio of sales expenses. The expansion of enterprises' assets was an essential driving factor for the implementation of blockchain technology.

The existing literature that used theoretical analysis and model construction methods has found that blockchain can reduce information asymmetry, friction, and transaction costs. It improves efficiency and the accuracy of accounting prediction, has the potential to support value creation, and realizes sustainable development goals, which should improve corporate performance $[28,33,34]$. However, we use Chinese data to test and find that the corporate performance has decreased after applying blockchain technology. Blockchain does not work as expected. Therefore, we will study the negative correlation between blockchain and corporate performance in this paper and deeply investigate the causes. We find that adverse selection is the leading cause for companies with lower performance using blockchain as a gimmick. The enterprises using blockchain are accompanied by the improvement of R\&D expenditure, investment expenditure, and patents. These enterprises only use blockchain to attract investors' attention, enabling the companies to gain short-term abnormal stock returns and improve the stock turnover rate. However, these companies do not give full attention to the role of blockchain due to the existing problems in enterprise operations. The benefits of adverse selection in enterprises are only temporary. The market-to-book ratio, government subsidy, and income growth rate of enterprises are still declining in the long term. The financial constraint has not been alleviated, and the performance of companies will continue to decline. In addition, we use heterogeneity tests and find that from the perspectives of the internal corporate governance environment, the lower proportion of largest shareholder, the more inferior quality of earning quality, and enterprises with non-state-owned property right are more inclined to use blockchain for adverse selection, and from the perspectives of the external microenvironment, the weaker the degree of marketization and law environment in the enterprises' areas, the higher the degree of adverse selection by blockchain.

The innovations of this paper are as follows: firstly, previous research studies mainly use case analysis, theoretical analysis, model construction, and other methods to study the application prospects, strategies, and advantages of blockchain. However, there are relatively few studies using actual data, and we use the data of Chinese listed companies to study. The advantage of Chinese data is that the Chinese government has launched policies to develop blockchain technology vigorously. Some companies have started to use blockchain technology gradually. There are sufficient data for empirical tests, helping to explore the conditions and problems of blockchain used in the virtual environment. Secondly, previous research mainly explored the advantages of blockchain applications from reducing information asymmetry and improving the level of trust. They did not consider whether the blockchain can achieve the expected goal. At the same time, the related problems in the practical application are not clear. We find that there is a negative correlation between blockchain and corporate performance. It is mainly caused by adverse selection, and we explore how to promote the blockchain to play a better effect from the prospects of corporate governance, earning quality, property rights, the degree of marketization, and the law environment in the region.

In this paper, China is chosen as the research object due to the following reasons. Firstly, as the country with relatively rapid economic development globally, China has the support of 5G, cloud platform, and other infrastructures, capable of using blockchain technology on a large scale. 
Secondly, the Chinese government encourages enterprises and governments to use blockchain technology strongly. There are many companies using blockchain, so we can use the empirical research method to test with large samples. Thirdly, there are many cities in China, where each city has a different level of the economic and legal environment and different local government policies, which is conducive to the heterogeneity tests in this paper.

The structure of this paper is as followed: the second part discusses the institutional background and development practices of blockchain; the third part is research hypotheses; the fourth part is data and model; the fifth part is empirical results, and the sixth part is conclusions and discussions.

\section{Institutional Background and Development Practices of Blockchain}

In China, blockchain has become an important strategy for national development. In December 2016, the "13th FiveYear Plan for National Informatization" firstly incorporated blockchain into national development plans. Many provinces and cities have issued documents to include the blockchain in development plans and have proposed policy supports for the blockchain. The president of China takes the blockchain and artificial intelligence as representatives of the new information technologies. Many financial institutions carry out blockchain business. For example, China Merchants Bank carries out blockchain cross-border direct settlement business, and Postal Savings Bank of China carries out blockchain letters of credit services and asset custody services. By using the distributed shared ledger and consensus mechanism of blockchain, the transaction information and process events can be shared by many parties on time, and the process of repeated credit checking can be avoided. The bank can drive the transaction process through the blockchain smart contract and realize the cross-institutional trust flow. The Bank of China cooperates with Tencent Financial Technology Group deeply in cloud computing, big data, blockchain, and artificial intelligence. They have developed digital wallets, trade finance, house leasing, public welfare, cross-border payments, digital bills, and other application scenarios. The China Zheshang Bank uses blockchain to develop accounts receivable platform, and the Shenzhen Stock Exchange uses blockchain to realize the information sharing between intermediary organizations in the regional stock market. In government affairs, Foshan City in Guangdong Province has applied blockchain technology to government services to speed up government affairs.

The Central Bank has issued digital currency, and Beijing has issued blockchain electronic invoices, parking tickets, and admission tickets, and Xiongan has set up a blockchain platform for government construction funds. In addition, there are many practical applications of blockchain in tax management, supply chain finance, the Internet of things, and so on. The technology of blockchain has a broad future with 5G, artificial intelligence, and the Internet of things. Many enterprises such as Baidu, Alibaba, Tencent, JD.com, Huawei, and others have started to develop blockchain applications, for example, Alibaba, which ranked fourth in Forbes's global blockchain in 2019. Its blockchain can realize cross-link data connection, distributed identity, trusted computing, application platform, and other services. It can provide other enterprises with finance, industry, government, and other comprehensive solutions. The applications include product traceability, financial leasing, risk management, marketing, health care, bills circulation, trusted data service platform, intellectual property protection, authentication, economic sharing, and other services. Huawei has also established a blockchain cloud platform to provide enterprises with blockchain support services such as supply chain finance, supply chain traceability, digital assets, crowdfunding, and notarization. Blockchain is also highly valued globally, and every country has its development and policy support on blockchain technology. In the financial field, Nasdaq has announced the launch of the blockchainbased equity trading platform Nasdaq Linq. It has approved the use of blockchain technology for stock trading, several states in America have authorized blockchain technology legislation, and the platform supports enterprises to issue "digital" equity to investors through blockchain technology. Morgan and Citibank apply for an interbank payment patent based on blockchain that allows banks to deal with crossborder payments in real-time without delays. The European Central Bank explores the blockchain actively and plans to issue digital money. The Deutsche Bundesbank and the Deutsche Börse have announced that they will collaborate to create a blockchain system for securities settlement. The Bank of Korea announces that South Korea's only stock exchange will develop a trading platform based on the blockchain. The Royal Bank of Canada begins to deploy a blockchain cross-border payment system. Australia Post applies blockchain technology to personal identification. Dubai establishes a global blockchain committee. On the corporate application level, IBM is one of the largest blockchain service providers, providing customers with solutions in the food industry, cross-border payments, finance, global trade, identity protection, etc. For example, Kroger uses IBM blockchain technology to achieve food traceability from farm to table.

The world's largest shipping company Maersk cooperates with IBM to create TradeLens, a blockchain global supply chain transportation system platform that can integrate parties to support information sharing and transparency and promote innovation. This platform has recorded more than 1.54 billion shipping events so far, including ship arrival times, container interfaces, customs release, commercial invoices, and bills of lading. Nuarca uses the blockchain to change the status of proxy voting completely. It retains $\mathrm{OBO}$ anonymity and can also ensure the transparency and auditability of the voting process. Buterin establishes the platform of Ethereal Square blockchain, constructs the framework of smart contracts, and applies the smart contract to blockchain for the first time. Ubiquity provides a platform for financial institutions and mortgage companies to use the real estate blockchain to record and track the transfer of land property right, title deeds, and liens, helping to ensure that documents are accurate and 
verifiable, and improve the transparency of transactions as well as reduce costs at the same time. Visa and DocuSign use blockchain technology to simplify car leasing. Customers select the car they want to rent, record it on the public ledger of blockchain, sign the lease agreement and insurance policy on the driver's seat, and update the blockchain information synchronously. Mitsui O.S.K., NYK, and other twelve steamboat Japanese companies have also formed a trade data sharing platform based on blockchain technology.

\section{Research Hypothesis}

We consider positive and negative conclusions on the effect of blockchain technology implementation on enterprise performance.

Firstly, the implementation of blockchain can improve the efficiency of enterprise operation. Blockchain can increase trust between enterprises, promote adaptability, agility, consistency, and performance of the supply chain [35]. Blockchain can also increase process efficiency in the implementation. It can reduce the number of staff processing operations, reduce the average time of order processing in the system, reduce the workload so that orders can be traceable, and improve the visibility of orders among various supply chain participants [1]. The blockchain uses a distributed system to record and trace transactions where each participant can access the information, view logistics, prices, dates, locations, qualities, certifications, customs documents, bills of lading, and other types of real-time data [36]. It can realize the real-time tracking of goods and transactions, promote the coordination and planning of materials and information, and avoid the efficiency loss caused by repeated operations. The transaction data on the blockchain can be traced permanently, which can reduce the time and cost of dispute settlement. In addition, blockchain technology reduces manual input data, reduces human error and manipulation, and reduces uncertainty and potential losses caused by grey-market transactions.

Secondly, the implementation of blockchain can reduce transaction costs and governance costs. According to the transaction cost theory, to maintain the relationship with the stakeholders, enterprises need to spend many governance costs. In traditional transactions, the parties need to make much investment to build trust and maintain the stability of long-term relationships and reduce opportunistic behavior. However, this trust can be easily broken by the more powerful trader. At the same time, blockchain can use technology to build trust and reduce transaction costs [37] and limit the impact of opportunistic behavior and environmental and behavioral uncertainty. The use of blockchain makes the transaction process transparent and verifiable and allows transactions to be recorded permanently without tampering, allowing improper records or behaviors to be traced. Simultaneously, all individuals in the blockchain can see the misconduct behavior, which can reduce individual opportunism, conduct collective supervision, and prevent theft, fraud, and manipulation. In addition, the smart contract can set parameters directly in the system and enforce them to avoid the default behavior
[38, 39]. Reducing transaction cost can make enterprises reduce the governance input, have more energy to invest in value-added activities, and improve enterprise performance.

Finally, blockchain can improve the quality of accounting information and business data, and data quality is an important factor affecting the profits of enterprises $[40,41]$. Blockchain can reduce the cost of collecting and validating data for enterprises, reducing the cost of collecting reputation information of supply chain partners, reducing the cost of signing agreements and subsequent tracking. Simultaneously, the smart contract can track the actions and performance of contract partners and can be terminated automatically in case of default. In addition, blockchain does not need to establish trust through long-term cooperation, so enterprises can find more trading partners to establish short-term dynamic relations [37]. According to the information asymmetry theory, to collect information and verify the reliability of the information, enterprises need to spend many costs. At the same time, blockchain can manage information data, guarantee authenticity through technical means, reduce information management costs, and improve enterprise performance. In conclusion, we propose $\mathrm{Hy}-$ pothesis $1 \mathrm{~A}$.

Hypothesis 1A: The use of blockchain can improve enterprise performance.

Some scholars have pointed out the threats and disadvantages of blockchain technology. For example, blockchain may endanger data privacy. The core enterprises in supply chains or industry chains may require other enterprises to provide complete and transparent data and use that data to monitor as a form of power and domination [7]. Although blockchain can realize the separation of powers, the promotion, and development of the blockchain is currently led by monopolistic parties, such as venture capitalists, global accounting firms, banks, and governments, they are more or more exclusive in blockchain development, widening the technological divide, increasing automation and layering, increasing the sovereignty of blockchain technologies, and sharing only limited data with specific enterprises, causing adverse effects on weak firms [42]. The use of blockchain may also be resistant by traditional intermediaries. The interface may not be very user-friendly during initial use, operational efficiency may be affected, and the blockchain cannot guarantee that the stored information is true and reliable; the information input from the source is wrong. The information flow in the process will also be wrong [4]. Furthermore, as a typical blockchain application, smart contracts require that all situations be considered and written into the code in advance. Contract terms cannot be modified, this will cause the loss of flexibility, and it may be difficult to adapt to dynamic market and supply chain environment and may conflict with existing legal frameworks [43]. In order to avoid the block chain bifurcation, it may need higher transaction cost, the realization of consensus mechanism will reduce the transaction confirmation speed, each node needs to store more redundant data, and executing common code and maintaining a common state will consume more resources for computing [44, 45]. 
In summary, we believe that the application of blockchain technology may impair enterprise performance in the following aspects. Firstly, the application of blockchain requires more upfront research and investment, such as building a blockchain technology platform and building systems among trading partners. These investments may not be profitable in the short term and require a lot of technical people to maintain, so that the enterprises gain less than the cost, resulting in a loss of enterprise profits [41, 42]. Secondly, because China's blockchain is at the primary and exploratory stage, most of the enterprises make use of the consortium blockchain, and the strengths of supply chain enterprises are unbalanced. Companies may not be possible to abandon the traditional transaction approach completely, they may form a pattern that the traditional transaction and blockchain transaction coexist, and the operators are not skilled. The function of blockchain may not be brought into full play, resulting in the decrease of efficiency and the decline of enterprise performance. Thirdly, the blockchain requires all participants to share transaction information. However, not all enterprises are willing to participate in the sharing activities, even if the blockchain can bring them a small increase in efficiency. The more participants, the more valuable the blockchain technology is, if the trading network is simple and small-scale, the blockchain will not play the scale effect, and blockchain has a high level of technical uncertainty at the early stages of development [37]. Fourthly, Chinese blockchain is generally set up by strong enterprises and invites other enterprises to participate in, monopoly and hierarchical systems may emerge gradually, and this may lead to enterprises unwilling to share data so that they can avoid the risk of data leakage, resulting in supply chain data isolation. Fifthly, there may be a problem of adverse selection in blockchain, some companies with poor management and weak governance are trying to attract more investors to buy their stocks and more customers to buy their products, and blockchain may be hyped as a concept. However, these companies have not invested and managed the blockchain, operation and governance problems have not been solved, and corporate performance will decline further. Therefore, we propose Hypothesis 1B.

Hypothesis 1B: The use of blockchain reduces enterprise performance.

\section{Data and Model}

In this section, we discuss the data and model in the context of relevant terminologies in detail.

4.1. Variable Definitions. We use corporate performance as the explanatory variable, measured by the rate of return on total assets (ROA). Moreover, we use the blockchain dummy variable and time dummy variable as explanatory variables. The blockchain dummy variable is whether the company uses blockchain technology in the sample period. We search the annual report text of listed companies. If the "blockchain" field appears during the whole sample period, the variable takes 1; otherwise, it takes 0 . A time dummy variable is a dummy variable that we take 1 during the year after adopting blockchain technology, otherwise 0 .

Following the works of the literature on corporate performance, we control the following firm characteristics in our analysis. Table 1 also lists the definition of variables:

(i) Size. We use the natural logarithm of the total assets at the end of the year to measure.

(ii) State. State-owned enterprises take 1, and nonstate-owned enterprises take 0 .

(iii) Lev. We use total liabilities divided by total assets to measure.

(iv) Largest. We use the proportion of shares held by the largest shareholder to measure.

(v) Firmage. We use the natural logarithm of the company's age after established to measure.

(vi) Growth. We use the growth rate of sales to measure.

(vii) MS. We use the proportion of corporate income in the industry to measure.

(viii) Year. It is an annual dummy variable. The variable definition table is shown in Table 1.

4.2. Data Sources. The data of this paper are from Chinese A-share listed companies in 2012 2019. The financial and governance data are from China Stock Market and Accounting Research Database (CSMAR). Following previous works of the literature, we deal with the data as follows: (1) delete the data of enterprises in the financial industry; (2) delete the samples of ST enterprises; (3) delete the missing values in the main regressions, and winsorize all variables at the 1st and 99th percentile to reduce the bias of outliers to the results.

4.3. Research Model. We take the DID + PSM model in this paper because different companies' years of implementing blockchain are not the same. We take the general DID model following Beck et al. [46]. Suppose the company has implemented blockchain technology from 2012 to 2019. In that case, we take the Treat 1 , otherwise 0 , and we define the Time dummy variable. We take 1 during the period after the company using blockchain technology and 0 before the period. The year is a dummy variable, and $u_{i}$ is the individual effect. When Treat $\times$ Time is positive, it shows that the use of blockchain technology can improve corporate performance. At the same time, PSM1:1 matching is carried out year by year according to whether enterprises use blockchain technology. We select the treatment group and control group and then expand into panel data.

In order to test hypothesis1, we set formula (1). If $a_{1}$ is significantly positive, then Hypothesis $1 \mathrm{~A}$ is true. If $a_{1}$ is significantly negative, then hypothesis $1 \mathrm{~B}$ is true: 
TABle 1: Variable definition table.

\begin{tabular}{|c|c|c|c|}
\hline Explained variable & Corporate performance & $R O A$ & Net profit/total assets \\
\hline \multirow{2}{*}{$\begin{array}{l}\text { Explanatory } \\
\text { variables }\end{array}$} & Blockchain dummy variable & Treat & $\begin{array}{l}\text { If the company uses the blockchain technology during the sample period, } \\
\text { we take } 1 \text {, otherwise } 0\end{array}$ \\
\hline & Time dummy variable & Time & $\begin{array}{c}\text { The year after the company adopts the blockchain technology is } 1 \text {, } \\
\text { otherwise } 0\end{array}$ \\
\hline \multirow{6}{*}{ Control variables } & $\begin{array}{l}\text { The company size } \\
\text { State-owned property right } \\
\text { Capital structure }\end{array}$ & $\begin{array}{l}\text { Size } \\
\text { State } \\
\text { Lev }\end{array}$ & $\begin{array}{c}\text { The natural logarithm of the total assets at the end of the year } \\
\text { State-owned enterprises take } 1 \text {, and non-state-owned enterprises take } 0 \\
\text { Total liabilities/total assets }\end{array}$ \\
\hline & $\begin{array}{l}\text { The proportion of the largest } \\
\text { shareholder }\end{array}$ & Largest & $\begin{array}{c}\text { Number of shares held by the most significant shareholder/total number } \\
\text { of shares }\end{array}$ \\
\hline & Firm age & Firmage & The natural logarithm of the company's age after established \\
\hline & Income growth rate & Growth & The growth rate of revenue \\
\hline & Market share & $M S$ & The proportion of corporate income in the industry \\
\hline & Year dummy variable & Year & Annual dummy variable \\
\hline
\end{tabular}

$$
\begin{aligned}
\text { ROA }_{\mathrm{it}}= & a_{0}+a_{1} \text { Treat }_{i} \times \text { Time }_{\mathrm{it}}+\text { Controls }_{\mathrm{it}} \\
& +u_{i}+\text { Year }_{t}+\varepsilon_{\mathrm{it}} .
\end{aligned}
$$

\section{Empirical Results}

In this section, we provide details about the results in graphical and tabular forms.

5.1. Descriptive Statistics. In this paper, we conduct balance tests on the PSM matching effect year by year. We find that there are significant differences between the treatment and control groups before matching, but no significant differences after matching. Taking 2016 as an example, which is an important node of Chinese blockchain policy, the results of Table 2 show that PSM matching can reduce the differences of variables between the treatment group and control group significantly. We can see this matching effect visually in Figure 1. We also make descriptive statistics on the sample of blockchain by year and by industry, the results are shown in Table 3 and Table 4, we can see that six listed companies began to use blockchain since 2015, after China issued the "13th FiveYear National Informatization Plan" in December 2016 and promoted blockchain development policy vigorously, more and more companies began to use blockchain technology, and there are already 510 listed companies using blockchain in 2019. At the same time, the industry of information technology has the largest proportion of companies developing and using blockchain, followed by industries of finance, leasing, and business services. In contrast, the manufacturing industry has the largest number of companies using blockchain, but the percentage in the industry is still slightly low. The result of the PSM matching balance test in 2016 is shown in Table 2. The effect of PSM before and after matching in 2016 is shown in Figure 1. We make PSM matching balance tests using the samples from the year 2012 to 2019 separately and list the results of 2016 as an example because this year is the beginning year that China starts to introduce policies to develop blockchain. We compare the variables before and after matching. The results show that after matching, the differences between the treatment and control groups have decreased significantly.
The table presents the number of listed companies using blockchain in China over 2012-2019. This paper presents the conditions of companies using blockchain in various industries in the year 2019. It lists the number of companies using blockchain in each industry, the overall number of companies in each industry, and the proportion.

Table 5 shows the descriptive statistics of the PSMmatched sample. The average return on total assets (ROA) is $3 \%$, and part of the companies' ROA is negative. The average proportion of the companies using blockchain is $18 \%$. Specifically, the treatment group has 2,698 samples. The control group has 12070 samples, mainly because we carry on PSM1:1 matching year by year and then expand to the panel data. There are big differences between the sample number of the treatment group and control group.

This table shows the descriptive statistics of samples in Chinese listed companies from a period in 2012-2019 after PSM matching. It includes mean value, standard deviation, minimum value, median value, and maximum value, the $R O A$ is the net profit/total assets. Treat is a dummy variable whether the company uses blockchain technology during the sample period. Size is the natural log of the total assets at the end of the year. State is a dummy variable whether the company is a state-owned company. Lev is total liabilities/ total assets. Largest is the percent of shares held by the largest shareholder. Firmage is the natural logarithm of the company's age after established. Growth is the growth rate of revenue, and $M S$ is the proportion of corporate income in the industry.

5.2. The Impact of Blockchain on Corporate Performance. Table 6 shows the effect of blockchain on corporate performance. We use full sample and PSM matching sample to test separately and take the DID method. The explained variable is corporate performance, which ROA measures. The explanatory variable is the cross-multiplication term of Treat and Time. We also control the individual effect and time effect of the companies.

Regressions (1)-(3) are results of full sample tests, regressions (1)-(2) adopt different control variables, respectively, and the conclusions are the same. It can be seen that the corporate performance decreases after adopting 
TABle 2: Result of the PSM matching balance test in 2016.

\begin{tabular}{|c|c|c|c|c|c|c|c|}
\hline & & Treatment group & Control group & $\begin{array}{c}\text { Standard deviation } \\
(\%)\end{array}$ & $\begin{array}{l}\text { Standard deviation } \\
\text { reduction }(\%)\end{array}$ & T statistic & $P>t$ \\
\hline \multirow{2}{*}{ Size } & Before match & 22.348 & 22.291 & 4.3 & \multirow{2}{*}{45.4} & 0.770 & 0.439 \\
\hline & After match & 22.348 & 22.378 & 2.4 & & 0.320 & 0.748 \\
\hline \multirow{2}{*}{ State } & Before match & 0.306 & 0.363 & 11.9 & \multirow{2}{*}{61.5} & $2.110^{*}$ & 0.035 \\
\hline & After match & 0.306 & 0.328 & 4.6 & & 0.630 & 0.527 \\
\hline \multirow{2}{*}{ Lev } & Before match & 0.394 & 0.432 & 18.4 & \multirow{2}{*}{86.2} & $3.230^{* * *}$ & 0.001 \\
\hline & After match & 0.394 & 0.399 & 2.5 & & 0.350 & 0.726 \\
\hline \multirow{2}{*}{ Largest } & Before match & 0.315 & 0.336 & 14.6 & \multirow{2}{*}{82} & $2.610^{* * *}$ & 0.009 \\
\hline & After match & 0.315 & 0.311 & 2.6 & & 0.370 & 0.714 \\
\hline \multirow{2}{*}{ Firmage } & Before match & 2.923 & 2.957 & 12.6 & \multirow{2}{*}{49.1} & $2.290^{* *}$ & 0.022 \\
\hline & After match & 2.923 & 2.905 & 6.4 & & 0.840 & 0.403 \\
\hline \multirow{2}{*}{ Growth } & Before match & 0.372 & 0.240 & 18.7 & \multirow{2}{*}{68.2} & $3.670^{* * *}$ & 0.000 \\
\hline & After match & 0.372 & 0.330 & 5.9 & & 0.750 & 0.455 \\
\hline \multirow{2}{*}{ MS } & Before match & 0.007 & 0.006 & 4.4 & \multirow{2}{*}{3.3} & 0.760 & 0.449 \\
\hline & After match & 0.007 & 0.008 & 4.5 & & 0.550 & 0.579 \\
\hline
\end{tabular}

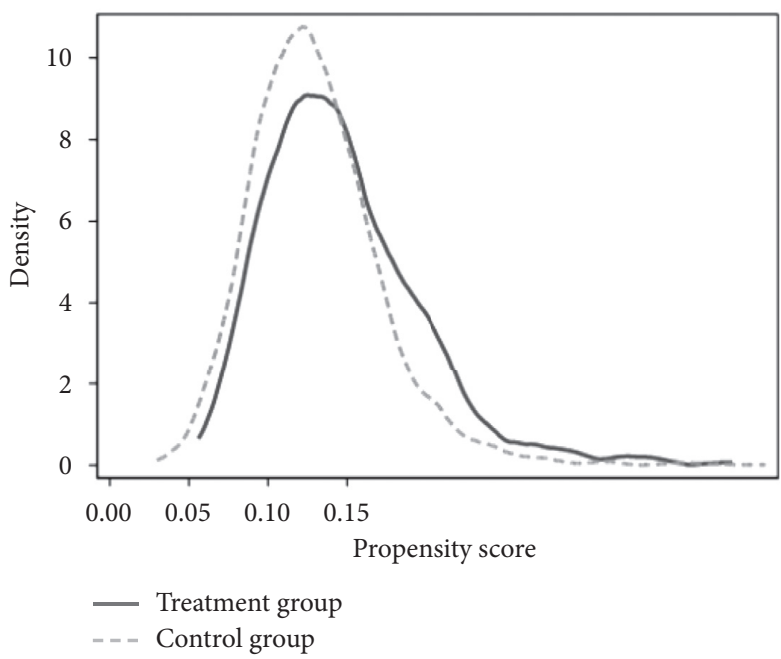

(a)

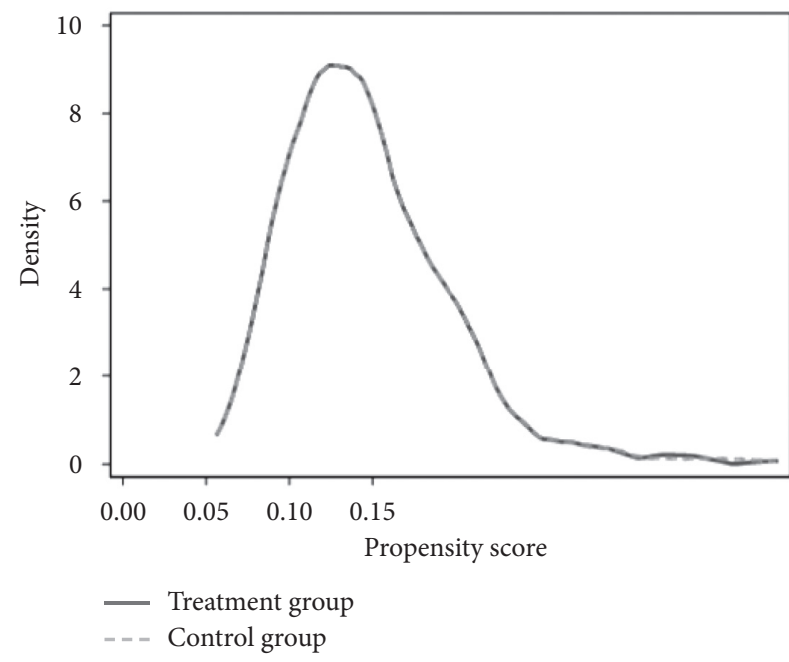

(b)

FIGURE 1: The effect of PSM before and after matching in 2016. (a) Before matching. (b) After matching.

TABle 3: Annual statistics of companies using blockchain technology.

\begin{tabular}{cccccccc}
\hline 2012 & 2013 & 2014 & 2015 & 2016 & 2017 & 2018 & 2019 \\
\hline 0 & 0 & 0 & 6 & 46 & 186 & 308 & 510 \\
\hline
\end{tabular}

TABLE 4: Industry statistics of companies using blockchain technology.

\begin{tabular}{|c|c|c|c|c|c|c|c|}
\hline The name of the industry & Number & $\begin{array}{l}\text { Total number } \\
\text { in the industry }\end{array}$ & Percent & The name of the industry & Number & $\begin{array}{l}\text { Total number } \\
\text { in the industry }\end{array}$ & $\begin{array}{c}\text { Percent } \\
(\%)\end{array}$ \\
\hline $\begin{array}{l}\text { Agriculture, forestry, animal } \\
\text { husbandry, and fishery }\end{array}$ & 4 & 42 & 9.52 & Real estate & 13 & 134 & 9.70 \\
\hline Mining & 3 & 77 & 3.90 & $\begin{array}{l}\text { Leasing and business } \\
\text { services }\end{array}$ & 20 & 57 & 35.09 \\
\hline Manufacturing & 162 & 2443 & 6.63 & $\begin{array}{l}\text { Scientific research and } \\
\text { technical services }\end{array}$ & 8 & 58 & 13.79 \\
\hline $\begin{array}{l}\text { Production and supply of } \\
\text { electricity, heat, gas, and water }\end{array}$ & 9 & 114 & 7.89 & $\begin{array}{l}\text { Water, environmental and } \\
\text { public utility management }\end{array}$ & 1 & 57 & 1.75 \\
\hline
\end{tabular}


TABLE 4: Continued.

\begin{tabular}{|c|c|c|c|c|c|c|c|}
\hline The name of the industry & Number & $\begin{array}{l}\text { Total number } \\
\text { in the industry }\end{array}$ & Percent & The name of the industry & Number & $\begin{array}{l}\text { Total number } \\
\text { in the industry }\end{array}$ & $\begin{array}{c}\text { Percent } \\
(\%)\end{array}$ \\
\hline Construction & 10 & 94 & 10.64 & $\begin{array}{l}\text { Residential services, } \\
\text { repairs, and other services }\end{array}$ & 0 & 1 & 0.00 \\
\hline Wholesale and retail & 29 & 175 & 16.57 & Education & 2 & 8 & 25.00 \\
\hline $\begin{array}{l}\text { Transportation, warehousing, and } \\
\text { postal services }\end{array}$ & 26 & 111 & 23.42 & Health and social work & 2 & 12 & 16.67 \\
\hline Accommodation and catering & 1 & 11 & 9.09 & $\begin{array}{l}\text { Culture, sports, and } \\
\text { entertainment }\end{array}$ & 13 & 59 & 22.03 \\
\hline $\begin{array}{l}\text { Information transmission, } \\
\text { software, and information } \\
\text { technology services }\end{array}$ & 160 & 303 & 52.81 & Comprehensive & 2 & 21 & 9.52 \\
\hline Finance & 45 & 112 & 40.18 & & & & \\
\hline
\end{tabular}

TABle 5: Descriptive statistics after PSM matching.

\begin{tabular}{|c|c|c|c|c|c|}
\hline Variables & Mean & $S d$ & Min & Median & Max \\
\hline$R O A$ & 0.03 & 0.07 & -0.36 & 0.03 & 0.21 \\
\hline Treat & 0.18 & 0.39 & 0.00 & 0.00 & 1.00 \\
\hline Size & 22.19 & 1.35 & 18.99 & 22.03 & 26.94 \\
\hline State & 0.36 & 0.48 & 0.00 & 0.00 & 1.00 \\
\hline Lev & 0.43 & 0.22 & 0.05 & 0.42 & 1.18 \\
\hline Largest & 0.34 & 0.15 & 0.09 & 0.31 & 0.75 \\
\hline Firmage & 2.92 & 0.29 & 1.95 & 2.94 & 3.56 \\
\hline Growth & 0.20 & 0.57 & -0.67 & 0.10 & 4.07 \\
\hline$M S$ & 0.01 & 0.02 & 0.00 & 0.00 & 0.13 \\
\hline$N$ & & & 14768 & & \\
\hline
\end{tabular}

TABLE 6: The effect of blockchain on corporate performance.

\begin{tabular}{|c|c|c|c|c|c|c|}
\hline & (1) & $\begin{array}{l}\text { (2) } \\
\text { All the samples }\end{array}$ & (3) & (4) & $\begin{array}{c}5) \\
\text { PSM } \\
\end{array}$ & (6) \\
\hline Treat $\times$ Time & $\begin{array}{c}-0.017^{* * *} \\
(0.000)\end{array}$ & $\begin{array}{c}-0.015^{* * *} \\
(0.001)\end{array}$ & & $\begin{array}{c}-0.017^{* * *} \\
(0.001)\end{array}$ & $\begin{array}{c}-0.014^{* * *} \\
(0.002)\end{array}$ & \\
\hline Treat $\times$ Year 2011 & & & $\begin{array}{l}-0.003 \\
(0.328)\end{array}$ & & & $\begin{array}{l}-0.003 \\
(0.465)\end{array}$ \\
\hline Treat $\times$ Year 2012 & & & $\begin{array}{l}-0.003 \\
(0.368)\end{array}$ & & & $\begin{array}{l}-0.002 \\
(0.648)\end{array}$ \\
\hline Treat $\times$ Year 2013 & & & $\begin{array}{c}0.001 \\
(0.879)\end{array}$ & & & $\begin{array}{c}0.002 \\
(0.642)\end{array}$ \\
\hline Treat $\times$ Year 2014 & & & $\begin{array}{l}-0.002 \\
(0.669)\end{array}$ & & & $\begin{array}{c}0.000 \\
(0.977)\end{array}$ \\
\hline Treat $\times$ Year 2015 & & & $\begin{array}{l}-0.001 \\
(0.896)\end{array}$ & & & $\begin{array}{c}0.001 \\
(0.827)\end{array}$ \\
\hline Treat $\times$ Year 2016 & & & $\begin{array}{c}-0.012^{* * *} \\
(0.009)\end{array}$ & & & $\begin{array}{c}-0.011^{* *} \\
(0.015)\end{array}$ \\
\hline Treat $\times$ Year 2017 & & & $\begin{array}{c}-0.009^{* *} \\
(0.046)\end{array}$ & & & $\begin{array}{c}-0.009^{*} \\
(0.051)\end{array}$ \\
\hline Treat $\times$ Year 2018 & & & $\begin{array}{c}-0.017^{* * *} \\
(0.006)\end{array}$ & & & $\begin{array}{c}-0.014^{* *} \\
(0.032)\end{array}$ \\
\hline Treat $\times$ Year 2019 & & & $\begin{array}{r}-0.006 \\
(0.195)\end{array}$ & & & $\begin{array}{l}-0.005 \\
(0.368)\end{array}$ \\
\hline Size & & $\begin{array}{c}0.018^{* * *} \\
(0.000)\end{array}$ & $\begin{array}{c}0.015^{* * *} \\
(0.000)\end{array}$ & & $\begin{array}{c}0.018^{* * *} \\
(0.000)\end{array}$ & $\begin{array}{c}0.015^{* * *} \\
(0.000)\end{array}$ \\
\hline State & & $\begin{array}{l}-0.006 \\
(0.269)\end{array}$ & $\begin{array}{l}-0.008 \\
(0.103)\end{array}$ & & $\begin{array}{l}-0.005 \\
(0.450)\end{array}$ & $\begin{array}{l}-0.008 \\
(0.194)\end{array}$ \\
\hline Lev & & $\begin{array}{c}-0.202^{* * *} \\
(0.000)\end{array}$ & $\begin{array}{c}-0.180^{* * * *} \\
(0.000)\end{array}$ & & $\begin{array}{c}-0.202^{* * *} \\
(0.000)\end{array}$ & $\begin{array}{c}-0.178^{* * *} \\
(0.000)\end{array}$ \\
\hline Largest & & $\begin{array}{c}0.041^{* * *} \\
(0.000)\end{array}$ & $\begin{array}{c}0.040^{* * *} \\
(0.000)\end{array}$ & & $\begin{array}{c}0.051^{* * *} \\
(0.000)\end{array}$ & $\begin{array}{c}0.045^{* * *} \\
(0.000)\end{array}$ \\
\hline
\end{tabular}


TABLE 6: Continued.

\begin{tabular}{|c|c|c|c|c|c|c|}
\hline & (1) & $\begin{array}{c}(2) \\
\text { All the samples }\end{array}$ & (3) & (4) & $\begin{array}{c}(5) \\
\text { PSM }\end{array}$ & (6) \\
\hline Firmage & & $\begin{array}{c}0.004 \\
(0.793)\end{array}$ & $\begin{array}{c}0.003 \\
(0.803)\end{array}$ & & $\begin{array}{c}0.014 \\
(0.399)\end{array}$ & $\begin{array}{c}0.015 \\
(0.261)\end{array}$ \\
\hline Growth & & $\begin{array}{c}0.019^{* * * *} \\
(0.000)\end{array}$ & $\begin{array}{c}0.019^{* * * *} \\
(0.000)\end{array}$ & & $\begin{array}{c}0.019^{* * *} \\
(0.000)\end{array}$ & $\begin{array}{c}0.019^{* * * *} \\
(0.000)\end{array}$ \\
\hline MS & & $\begin{array}{c}0.294^{* * *} \\
(0.002)\end{array}$ & $\begin{array}{c}0.286^{* * *} \\
(0.001)\end{array}$ & & $\begin{array}{c}0.293^{* * *} \\
(0.004)\end{array}$ & $\begin{array}{c}0.269^{* * *} \\
(0.003)\end{array}$ \\
\hline Constant & $\begin{array}{c}0.036^{* * *} \\
(0.000)\end{array}$ & $\begin{array}{c}-0.309^{* * *} \\
(0.000)\end{array}$ & $\begin{array}{c}-0.217^{* * *} \\
(0.000)\end{array}$ & $\begin{array}{c}0.037^{* * *} \\
(0.000)\end{array}$ & $\begin{array}{c}-0.344^{* * *} \\
(0.000)\end{array}$ & $\begin{array}{c}-0.245^{* * *} \\
(0.000)\end{array}$ \\
\hline Year & Control & Control & Control & Control & Control & Control \\
\hline Fixed effects & Control & Control & Control & Control & Control & Control \\
\hline Number & 20695 & 20695 & 24489 & 14768 & 14768 & 17579 \\
\hline$R^{2}$ & 0.025 & 0.213 & 0.213 & 0.028 & 0.217 & 0.212 \\
\hline$F$ value & $29.369^{* * *}$ & $82.384^{* * *}$ & $64.662^{* * *}$ & $22.968^{* * *}$ & $63.752^{* * *}$ & $49.131^{* * *}$ \\
\hline
\end{tabular}

blockchain, which is consistent with hypothesis H1b. Regression (3) is a result of the balance trend test. It can be seen that the negative impact of blockchain on corporate performance starts from 2016, while blockchain has no significant impact on corporate performance before 2016, which is consistent with the time cutoff point that China begins to develop blockchain technology vigorously since 2016. Blockchain needs a lot of investment and research costs, which may lead to falling profits. The employees may not be familiar with the operation process. There may not be enough cooperative companies to participate in the blockchain, which will cause a decrease in corporate profit. There may be other reasons, such as the adverse selection. The enterprise with worse performance is more inclined to use blockchain for hype. At the same time, the defects of company operation are not solved, resulting in the decline of performance. We will test and analyze the reasons in later sections. Regressions (4)-(6) are results of tests using samples after PSM matching, and the conclusions are consistent with previous. In addition, we can also see from the control variables that the larger size, the higher ratio of the largest shareholder, the better growth rate, the larger market share of the company is accompanied by better corporate performance. In contrast, the larger debt ratio is accompanied by worse corporate performance, consistent with our cognition.

This table shows the regression results of the DID model. The explained variable is corporate performance, which is profit divided by total assets. This sample is listed companies in the CSMAR database from 2012 to 2019. In regressions (1)-(3), we use the full sample; in regressions (4)-(6), we use the sample after PSM matching. We set the year as dummy variables to cross-multiply with Treat to test the equilibrium trend in regressions (3) and (6). The $p$ values in parentheses are standard errors based on heteroskedasticity-consistent. The symbols ${ }^{* * *},{ }^{* *}$, and ${ }^{*}$ indicate statistical significance at the $1 \%, 5 \%$, and $10 \%$ levels, respectively.

5.3. Alternative Hypothesis: Reverse Causality. So far, we have shown that blockchain can reduce firm performance. Alternatively, is it because firms with lower performance use blockchain as a way of hype in order to attract more investment? Blockchain is a technology that China promotes vigorously now. Enterprises using blockchain technology may receive more state subsidies and have higher market responses in the stock market. According to this alternative hypothesis, enterprises with lower performance are more inclined to adopt blockchain technology. For example, on December 14, 2017, Longfin went public on the Nasdaq, bought a smart contract platform "http://www.ziddu.com" on the next day, and its share price rose more than $2,000 \%$ in two days. In December 2017, Riot Blockchain saw its share price soar to $\$ 40$ after it announced a transition to cryptocurrency-related services. According to the information asymmetry theory, outside investors or traders can only see whether enterprises adopt blockchain technology but do not know how to implement blockchain, and blockchain is a new technology that needs large investment but has a slow effect. Therefore, companies with average performance may be reluctant to invest in blockchain technology which may cause losses, and only companies with certain strengths are willing to invest in blockchain as industry pioneers, but the number is rare. In addition, a group of companies treat blockchain as a gimmick to the hype, but whether blockchain can play a good effect is not clear, and such companies may occupy a high proportion, resulting in a reverse selection phenomenon.

We set up the logit model and probit model to test this hypothesis. The explained variable is a dummy variable whether the blockchain technology is used in the current year. The explanatory variables are $R O A$ in the current and one lagged year, respectively. Because companies in China start to use blockchain in 2016, we set the sample period from 2016 to 2019. The results are as shown in Table 7. We can see from the results that no matter which model is used, firm performance is negatively related to adopting blockchain technology. The enterprises with worse performance are more inclined to use blockchain technology.

To verify whether the disadvantages and defects of blockchain result in the decrease of enterprise performance, or whether the adverse selection leads to the enterprises with poor performance are more inclined to adopt blockchain technology? We examine the impact of blockchain 
TABle 7: Adverse selection test.

\begin{tabular}{|c|c|c|c|c|}
\hline & (1) & (2) & (3) & (4) \\
\hline & & & \multicolumn{2}{|c|}{ Probit } \\
\hline$R O A$ & $\begin{array}{c}-2.179^{* * *} \\
(0.000)\end{array}$ & & $\begin{array}{c}-1.093^{* * *} \\
(0.001)\end{array}$ & \\
\hline L.ROA & & $\begin{array}{c}-1.570^{*} \\
(0.052)\end{array}$ & & $\begin{array}{c}-0.685^{*} \\
(0.092)\end{array}$ \\
\hline Size & $\begin{array}{c}0.187^{* * *} \\
(0.001)\end{array}$ & $\begin{array}{c}0.171^{* * *} \\
(0.003)\end{array}$ & $\begin{array}{c}0.091^{* * *} \\
(0.001)\end{array}$ & $\begin{array}{c}0.082^{* * *} \\
(0.003)\end{array}$ \\
\hline State & $\begin{array}{c}-0.437^{* * *} \\
(0.003)\end{array}$ & $\begin{array}{c}-0.453^{* * *} \\
(0.002)\end{array}$ & $\begin{array}{c}-0.214^{* * *} \\
(0.002)\end{array}$ & $\begin{array}{c}-0.220^{* * *} \\
(0.002)\end{array}$ \\
\hline Lev & $\begin{array}{c}-0.815^{* *} \\
(0.023)\end{array}$ & $\begin{array}{c}-0.615^{*} \\
(0.087)\end{array}$ & $\begin{array}{c}-0.386^{* *} \\
(0.027)\end{array}$ & $\begin{array}{l}-0.277 \\
(0.105)\end{array}$ \\
\hline Largest & $\begin{array}{c}-2.032^{* * *} \\
(0.000)\end{array}$ & $\begin{array}{c}-2.127^{* * *} \\
(0.000)\end{array}$ & $\begin{array}{c}-0.994^{* * *} \\
(0.000)\end{array}$ & $\begin{array}{c}-1.042^{* * *} \\
(0.000)\end{array}$ \\
\hline Firmage & $\begin{array}{c}-0.425^{*} \\
(0.052)\end{array}$ & $\begin{array}{c}-0.437^{* *} \\
(0.045)\end{array}$ & $\begin{array}{c}-0.223^{* *} \\
(0.037)\end{array}$ & $\begin{array}{c}-0.226^{* *} \\
(0.034)\end{array}$ \\
\hline Growth & $\begin{array}{l}-0.078 \\
(0.429)\end{array}$ & $\begin{array}{l}-0.153 \\
(0.146)\end{array}$ & $\begin{array}{l}-0.036 \\
(0.451)\end{array}$ & $\begin{array}{l}-0.071 \\
(0.163)\end{array}$ \\
\hline$M S$ & $\begin{array}{c}5.209 \\
(0.126)\end{array}$ & $\begin{array}{c}5.236 \\
(0.122)\end{array}$ & $\begin{array}{c}2.725 \\
(0.120)\end{array}$ & $\begin{array}{c}2.725 \\
(0.118)\end{array}$ \\
\hline Constant & $\begin{array}{c}-3.773^{* * *} \\
(0.006)\end{array}$ & $\begin{array}{c}-3.453^{* *} \\
(0.012)\end{array}$ & $\begin{array}{c}-1.978^{* * *} \\
(0.003)\end{array}$ & $\begin{array}{c}-1.817^{* * *} \\
(0.007)\end{array}$ \\
\hline Year & Control & Control & Control & Control \\
\hline Number & 10857 & 10857 & 10857 & 10857 \\
\hline$R^{2}$ & 0.076 & 0.074 & 0.077 & 0.074 \\
\hline Chi value & $298.423^{* * *}$ & $283.482^{* * *}$ & $322.278^{* * *}$ & $310.039^{* * *}$ \\
\hline
\end{tabular}

TABLE 8: The effect of the blockchain implementation on R\&D and investment activities.

\begin{tabular}{|c|c|c|c|c|c|c|}
\hline & (1) & (2) & (3) & (4) & (5) & (6) \\
\hline & \multicolumn{2}{|c|}{ Research } & \multicolumn{2}{|c|}{ Invest } & \multicolumn{2}{|c|}{ Patent } \\
\hline & Full sample & PSM & Full sample & PSM & Full sample & PSM \\
\hline Treat $\times$ Time & $\begin{array}{c}-0.006^{* * *} \\
(0.000)\end{array}$ & $\begin{array}{c}-0.005^{* * *} \\
(0.000)\end{array}$ & $\begin{array}{c}-0.004^{*} \\
(0.054)\end{array}$ & $\begin{array}{c}-0.005^{* *} \\
(0.026)\end{array}$ & $\begin{array}{c}-0.116^{* *} \\
(0.029)\end{array}$ & $\begin{array}{c}-0.097^{*} \\
(0.072)\end{array}$ \\
\hline Size & $\begin{array}{c}-0.007^{* * *} \\
(0.000)\end{array}$ & $\begin{array}{c}-0.007^{* * * *} \\
(0.000)\end{array}$ & $\begin{array}{c}0.004^{* * * *} \\
(0.002)\end{array}$ & $\begin{array}{c}0.004^{* * * *} \\
(0.001)\end{array}$ & $\begin{array}{c}0.005 \\
(0.812)\end{array}$ & $\begin{array}{l}-0.010 \\
(0.699)\end{array}$ \\
\hline State & $\begin{array}{l}-0.001 \\
(0.415)\end{array}$ & $\begin{array}{l}-0.001 \\
(0.649)\end{array}$ & $\begin{array}{c}-0.009^{* *} \\
(0.019)\end{array}$ & $\begin{array}{c}-0.009^{* *} \\
(0.036)\end{array}$ & $\begin{array}{c}0.113 \\
(0.199)\end{array}$ & $\begin{array}{c}0.134 \\
(0.208)\end{array}$ \\
\hline Lev & $\begin{array}{c}-0.006^{* * *} \\
(0.000)\end{array}$ & $\begin{array}{c}-0.005^{* *} \\
(0.015)\end{array}$ & $\begin{array}{c}-0.013^{* * * *} \\
(0.001)\end{array}$ & $\begin{array}{c}-0.012^{* * * *} \\
(0.006)\end{array}$ & $\begin{array}{c}0.015 \\
(0.850)\end{array}$ & $\begin{array}{c}0.028 \\
(0.763)\end{array}$ \\
\hline Largest & $\begin{array}{c}0.003 \\
(0.401)\end{array}$ & $\begin{array}{c}0.001 \\
(0.848)\end{array}$ & $\begin{array}{c}0.025^{* * *} \\
(0.001)\end{array}$ & $\begin{array}{l}0.021^{* *} \\
(0.016)\end{array}$ & $\begin{array}{l}-0.043 \\
(0.828)\end{array}$ & $\begin{array}{l}-0.079 \\
(0.735)\end{array}$ \\
\hline Firmage & $\begin{array}{c}-0.017^{* * *} \\
(0.000)\end{array}$ & $\begin{array}{c}-0.018^{* * *} \\
(0.000)\end{array}$ & $\begin{array}{c}-0.077^{* * *} \\
(0.000)\end{array}$ & $\begin{array}{c}-0.076^{* * *} \\
(0.000)\end{array}$ & $\begin{array}{l}-0.425 \\
(0.198)\end{array}$ & $\begin{array}{l}-0.451 \\
(0.215)\end{array}$ \\
\hline Growth & $\begin{array}{l}0.001^{* *} \\
(0.011)\end{array}$ & $\begin{array}{l}0.001^{* *} \\
(0.022)\end{array}$ & $\begin{array}{c}-0.001 \\
(0.345)\end{array}$ & $\begin{array}{c}-0.001^{*} \\
(0.079)\end{array}$ & $\begin{array}{l}-0.019 \\
(0.164)\end{array}$ & $\begin{array}{l}-0.004 \\
(0.768)\end{array}$ \\
\hline$M S$ & $\begin{array}{l}0.058^{* *} \\
(0.032)\end{array}$ & $\begin{array}{l}0.056^{*} \\
(0.061)\end{array}$ & $\begin{array}{c}0.014 \\
(0.872)\end{array}$ & $\begin{array}{l}-0.042 \\
(0.632)\end{array}$ & $\begin{array}{c}1.481 \\
(0.232)\end{array}$ & $\begin{array}{c}1.154 \\
(0.336)\end{array}$ \\
\hline Constant & $\begin{array}{c}0.235^{* * * *} \\
(0.000)\end{array}$ & $\begin{array}{c}0.247^{* * * *} \\
(0.000)\end{array}$ & $\begin{array}{c}0.196^{* * * *} \\
(0.000)\end{array}$ & $\begin{array}{c}0.179^{* * * *} \\
(0.001)\end{array}$ & $\begin{array}{c}1.685 \\
(0.141)\end{array}$ & $\begin{array}{c}2.106 \\
(0.102)\end{array}$ \\
\hline Year & Control & Control & Control & Control & Control & Control \\
\hline Fixed effect & Control & Control & Control & Control & Control & Control \\
\hline Number & 20516 & 14679 & 20672 & 14747 & 20695 & 14768 \\
\hline$R^{2}$ & 0.336 & 0.341 & 0.089 & 0.094 & 0.008 & 0.010 \\
\hline F value & $157.618^{* * *}$ & $120.383^{* * *}$ & $47.951^{* * *}$ & $37.696^{* * *}$ & $7.604^{* * *}$ & $6.677^{* * *}$ \\
\hline
\end{tabular}

implementation on $\mathrm{R} \& \mathrm{D}$ expenditure, investment expenditure, and the number of patents. The results are shown in Table 8 . We use the DID model to test, the explained variables are $\mathrm{R} \& \mathrm{D}$ expenditure divided by the total assets, the cash paid for fixed assets and intangible assets divided by total assets, and the natural logarithm of the number of patents, the explanatory variable is the cross-multiplication term of Treat and Time, and we use full sample and PSM- 
matched sample to test separately. Suppose enterprises want to make full use of blockchain technology for development, due to the strong specialization of blockchain technology. In that case, enterprises adopting blockchain should increase their R\&D investment or purchase the existing blockchain information system, the enterprises' R\&D expenditure, and investment expenditure, and the number of patents should increase. However, as we can see from the results of Table 8, enterprises' $R \& D$ expenditure, investment expenditure, and the number of patents have decreased after using blockchain technology, and this also proves the existence of adverse selection, although several enterprises mention their use of blockchain technology in the annual reports, but they do not really carry out research or investment and use the blockchain only as a way of hype.

Based on the above results, we can conclude as follows: the negative relationship between blockchain and enterprise performance is due to adverse selection, the enterprises with lower performance are more inclined to use blockchain to the hype, but these enterprises do not increase the $R \& D$ expenditure or investment expenditure to carry out blockchain activities, and the number of patents does not increase, at the same time, because the internal management problems of enterprises do not improve timely, enterprise performance will be lower and lower.

This table reports the regression results using the logit and probit models. The dependent variable is a dummy variable of whether the company uses blockchain in the current year. The independent variable is $R O A$ and $R O A$ with one lag. This sample is listed companies in the CSMAR database from 2016 to 2019 because companies are beginning to use blockchain since 2016. The $p$ values in parentheses are standard errors based on heteroskedasticityconsistent. The symbols ${ }^{* * *},{ }^{* *}$, and ${ }^{*}$ indicate statistical significance at the $1 \%, 5 \%$, and $10 \%$ levels, respectively.

This table reports the regression results using the DID model. The dependent variables are Research, Invest, and Patent in different regressions. Research is R\&D expenditure divided by the total assets. Invest is the cash paid for fixed assets and intangible assets divided by total assets. Patent is the natural logarithm of the number of patents. The independent variable is the cross-multiplication term of Treat and Time. This sample is listed companies in the CSMAR database from 2012 to 2019 . We use the full sample and PSM-matched sample to test in different regressions. The $p$ values in parentheses are standard errors based on heteroskedasticity-consistent. The symbols ${ }^{* * *},{ }^{* *}$, and ${ }^{*}$ indicate statistical significance at the $1 \%, 5 \%$, and $10 \%$ levels, respectively.

5.4. The Economic Consequences of Blockchain Adverse Selection. In order to investigate why enterprises use blockchain to the hype, we study the economic consequences of blockchain implementation from the perspectives of the stock market and internal financial condition.

5.4.1. Impact on the Company's Stock. As one of the technologies that the Chinese government is developing vigorously, blockchain has broad prospects in the future. Investors will also see the blockchain as an investment opportunity and are willing to invest in companies that implement blockchain technology. As a result, when the company's annual report discloses the information about blockchain, investors will be more willing to buy stocks of the company, the company's abnormal stock returns will be higher, and the liquidity of the stock will be better. Emshwiller [47] found that in the development period of the Internet when companies add ".com" to their names, their stock prices would rise rapidly but can only last about 10 days. Jain and Jain [29] found that companies changing their names to include blockchain fields can receive short-term abnormal stock returns.

This paper uses the cumulative abnormal return (CAR) of an annual report released between -3 days and 3 days and the annual average rate of stock turnover as explained variables. The results are shown in Table 9. We find the values of CAR and stock turnover rate raise when the enterprises begin to use blockchain. These are also the motivations of enterprises willing to use blockchain to hype. Because of the asymmetric information between enterprises and external investors, investors do not know whether enterprises make full use of blockchain, so investors will give a higher market reaction to enterprises that disclose the blockchain plan in their annual reports. The increase in stock turnover also shows that the disclosure of blockchain information can attract many investors to buy the company's stocks. At the same time, we also use the M/B index as an explanatory variable to test, which can reflect the long-term stock value, and find $\mathrm{M} / \mathrm{B}$ index declines after the implementation of blockchain, and it shows that even if blockchain can attract investors in the short term, investors can still be able to identify whether enterprises make use of the blockchain effectively to operational activities in the long term.

5.4.2. Impact on the Company's Financial Conditions. We further examine the impact of blockchain implementation on corporates' financial conditions, such as financial constraints, government subsidies, and income growth rate. Firstly, suppose enterprises make full use of blockchain to build information platform. In that case, enterprises' transparency will improve, and the information asymmetry between firms and stakeholders such as banks, governments, suppliers, and customers will decrease; the improvement of information transparency can increase the availability of corporate loans. Banks are more willing to lend to firms [48], and corporate financial constraints will be lowered. Secondly, suppliers and customers will be able to trace the company's product information, reducing the cost of information communication and dispute resolution $[3,49]$, suppliers and customers will be more willing to cooperate with the enterprise, and the enterprise's income will increase. Thirdly, considering the government's strong support for blockchain technology, the enterprise using blockchain will get more innovation subsidies from the government. If an adverse selection exists, enterprises with 
TABLE 9: The effect of blockchain implementation on corporate's stock.

\begin{tabular}{|c|c|c|c|c|c|c|}
\hline & (1) & \multirow[t]{2}{*}{ (2) } & \multirow{2}{*}{\multicolumn{2}{|c|}{ (3) Stock_Turnover }} & (5) & (6) \\
\hline & $C A R$ & & & & \multicolumn{2}{|c|}{$M / B$ ratio } \\
\hline & Full sample & PSM & Full sample & PSM & Full sample & PSM \\
\hline \multirow{2}{*}{ Treat $\times$ Time } & $0.009^{* *}$ & $0.009^{* *}$ & $27.332^{* *}$ & $27.622^{* *}$ & $-0.368^{* *}$ & $-0.458^{* * *}$ \\
\hline & $(0.047)$ & $(0.038)$ & $(0.020)$ & $(0.020)$ & $(0.029)$ & $(0.008)$ \\
\hline \multirow{2}{*}{ Size } & $-0.003^{*}$ & -0.003 & $-52.153^{* * *}$ & $-54.650^{* * *}$ & $-1.993^{* * *}$ & $-2.010^{* * *}$ \\
\hline & $(0.075)$ & $(0.176)$ & $(0.000)$ & $(0.000)$ & $(0.000)$ & $(0.000)$ \\
\hline \multirow{2}{*}{ State } & 0.006 & 0.008 & $41.171^{* * *}$ & 16.988 & $-0.583^{*}$ & -0.277 \\
\hline & $(0.233)$ & $(0.180)$ & $(0.008)$ & $(0.340)$ & $(0.094)$ & $(0.471)$ \\
\hline \multirow{2}{*}{ Lev } & -0.001 & 0.002 & $108.560^{* * *}$ & $116.840^{* * *}$ & $5.158^{* * *}$ & $5.683^{* * *}$ \\
\hline & $(0.859)$ & $(0.747)$ & $(0.000)$ & $(0.000)$ & $(0.000)$ & $(0.000)$ \\
\hline \multirow{2}{*}{ Largest } & 0.010 & 0.011 & $-198.987^{* * *}$ & $-205.433^{* * *}$ & 0.004 & 0.022 \\
\hline & $(0.371)$ & $(0.365)$ & $(0.000)$ & $(0.000)$ & $(0.994)$ & $(0.977)$ \\
\hline \multirow{2}{*}{ Firmage } & 0.005 & 0.012 & 66.712 & 54.331 & -1.163 & -0.137 \\
\hline & $(0.758)$ & $(0.531)$ & $(0.157)$ & $(0.315)$ & $(0.129)$ & $(0.866)$ \\
\hline \multirow{2}{*}{ Growth } & 0.001 & 0.001 & 5.018 & $6.933^{*}$ & $0.247^{* * *}$ & $0.275^{* * *}$ \\
\hline & $(0.625)$ & $(0.399)$ & (0.109) & $(0.066)$ & $(0.000)$ & $(0.000)$ \\
\hline \multirow{2}{*}{$M S$} & 0.127 & 0.099 & 328.705 & 256.640 & $17.471^{* *}$ & $18.135^{* *}$ \\
\hline & $(0.255)$ & $(0.425)$ & $(0.266)$ & $(0.424)$ & $(0.024)$ & $(0.028)$ \\
\hline \multirow{2}{*}{ Constant } & 0.054 & 0.023 & $1322.697^{* * *}$ & $1431.795^{* * *}$ & $49.044^{* * *}$ & $46.114^{* * *}$ \\
\hline & $(0.369)$ & $(0.745)$ & $(0.000)$ & $(0.000)$ & $(0.000)$ & $(0.000)$ \\
\hline Year & Control & Control & Control & Control & Control & Control \\
\hline Fixed effect & Control & Control & Control & Control & Control & Control \\
\hline Number & 15053 & 10714 & 20653 & 14737 & 20658 & 14741 \\
\hline$R^{2}$ & 0.003 & 0.004 & 0.380 & 0.388 & 0.228 & 0.232 \\
\hline$F$ value & $2.353^{* * *}$ & $2.099^{* * *}$ & $420.770^{* * *}$ & $319.937^{* * *}$ & $137.441^{* * *}$ & $96.850^{* * *}$ \\
\hline
\end{tabular}

lower performance will exaggerate the application of blockchain in their annual reports to attract other partners' attention. The result will be the opposite. Banks, suppliers, and customers, as the main partners, trade directly with enterprises. They have a full understanding of the enterprises' conditions, the government can also conduct a direct investigation of enterprises, and they can identify the adverse selection behavior of enterprises. Enterprises that just use blockchain to hype will not get more bank loans, income, and government subsidies. Therefore, we use financial constraints, innovation subsidies, income growth rate as the explained variables to test. The results are shown in Table 10. It can be seen that after the implementation of blockchain, enterprises' financial constraints increase and innovation subsidies decrease. Income growth rate decreases, which is consistent with the conclusion of adverse selection, it shows that the blockchain in enterprises does not play a role, and these enterprises do not make full advantage of blockchain to develop, but only as a way of hype.

This table reports the regression results using the DID model. The dependent variables are CAR, Stock_Turnover, and $M / B$ ratio in different regressions. $C A R$ is the cumulative abnormal return of annual report released between -3 days and 3 days, Stock_Turnover is the annual average rate of stock turnover, $M / B$ ratio is market value divided by book value, and the independent variable is the cross-multiplication term of Treat and Time. This sample is listed companies in the CSMAR database from 2012 to 2019. We use the full sample and PSM-matched sample to test in different regressions. The $p$ values in parentheses are standard errors based on heteroskedasticity-consistent. The symbols ***, **, and ${ }^{*}$ indicate statistical significance at the $1 \%, 5 \%$, and $10 \%$ levels, respectively.

This table reports the regression results using the DID model. The dependent variables are FC, Subsidy, and Growth in different regressions, $F C$ is calculated following Wang [50] using investment efficiency index, Subsidy is the government subsidy for company innovation divided by operating cost, Growth is the income growth rate, and the independent variable is the cross-multiplication term of Treat and Time. This sample is listed companies in the CSMAR database from 2012 to 2019. We use the full sample and PSM-matched sample to test in different regressions. The $p$ values in parentheses are standard errors based on heteroskedasticity-consistent. The symbols ***,**, and * indicate statistical significance at the $1 \%, 5 \%$, and $10 \%$ levels, respectively.

5.5. Heterogeneity Tests of Blockchain Reverse Selection. In order to examine the factors that affect the blockchain reverse selection of enterprises further, put forward countermeasures to reduce the adverse selection of enterprises, and give full play to the advantages of the blockchain, we make heterogeneity tests, analyze the factors from the prospects of corporate governance and the external macroenvironment.

\subsubsection{Corporate Governance Environment}

(1) The shareholding ratio of largest shareholder: there are agency problems and information asymmetry between managers and shareholders in a company. 
TABLE 10: The effect of blockchain implementation on the company's financial conditions.

\begin{tabular}{|c|c|c|c|c|c|c|}
\hline & (1) & \multirow[t]{2}{*}{ (2) } & (3) & \multirow[t]{2}{*}{ (4) } & \multirow{2}{*}{\multicolumn{2}{|c|}{ Growth }} \\
\hline & $F C$ & & Subsidy & & & \\
\hline & Full sample & PSM & Full sample & PSM & Full sample & PSM \\
\hline Treat $\times$ Time & $\begin{array}{c}0.020^{* * *} \\
(0.000)\end{array}$ & $\begin{array}{c}0.020^{* * *} \\
(0.000)\end{array}$ & $\begin{array}{c}-0.002^{* *} \\
(0.022)\end{array}$ & $\begin{array}{c}-0.002^{* *} \\
(0.028)\end{array}$ & $\begin{array}{c}-0.172^{* * *} \\
(0.000)\end{array}$ & $\begin{array}{c}-0.166^{* * *} \\
(0.000)\end{array}$ \\
\hline Size & $\begin{array}{c}-0.072^{* * *} \\
(0.000)\end{array}$ & $\begin{array}{c}-0.073^{* * *} \\
(0.000)\end{array}$ & $\begin{array}{c}0.000 \\
(0.471)\end{array}$ & $\begin{array}{c}0.000 \\
(0.408)\end{array}$ & $\begin{array}{c}0.234^{* * *} \\
(0.000)\end{array}$ & $\begin{array}{c}0.237^{* * *} \\
(0.000)\end{array}$ \\
\hline State & $\begin{array}{c}0.019^{* * *} \\
(0.010)\end{array}$ & $\begin{array}{l}0.014^{*} \\
(0.078)\end{array}$ & $\begin{array}{l}-0.000 \\
(0.572)\end{array}$ & $\begin{array}{c}0.000 \\
(0.861)\end{array}$ & $\begin{array}{c}-0.159^{* * *} \\
(0.004)\end{array}$ & $\begin{array}{c}-0.143^{* *} \\
(0.027)\end{array}$ \\
\hline Lev & $\begin{array}{c}-0.036^{* * *} \\
(0.000)\end{array}$ & $\begin{array}{c}-0.037^{* * *} \\
(0.000)\end{array}$ & $\begin{array}{c}-0.004^{* * *} \\
(0.000)\end{array}$ & $\begin{array}{c}-0.004^{* * *} \\
(0.000)\end{array}$ & $\begin{array}{l}-0.070 \\
(0.243)\end{array}$ & $\begin{array}{l}-0.098 \\
(0.166)\end{array}$ \\
\hline Largest & $\begin{array}{c}-0.027^{*} \\
(0.051)\end{array}$ & $\begin{array}{l}-0.019 \\
(0.220)\end{array}$ & $\begin{array}{c}0.001 \\
(0.524)\end{array}$ & $\begin{array}{c}0.001 \\
(0.474)\end{array}$ & $\begin{array}{c}0.412^{* * *} \\
(0.000)\end{array}$ & $\begin{array}{c}0.405^{* * *} \\
(0.002)\end{array}$ \\
\hline Firmage & $\begin{array}{c}0.177^{* * *} \\
(0.000)\end{array}$ & $\begin{array}{c}0.181^{* * *} \\
(0.000)\end{array}$ & $\begin{array}{c}-0.005^{*} \\
(0.085)\end{array}$ & $\begin{array}{l}-0.004 \\
(0.245)\end{array}$ & $\begin{array}{l}0.279^{* *} \\
(0.035)\end{array}$ & $\begin{array}{l}0.272^{*} \\
(0.070)\end{array}$ \\
\hline Growth & $\begin{array}{c}-0.024^{* * *} \\
(0.000)\end{array}$ & $\begin{array}{c}-0.022^{* * *} \\
(0.000)\end{array}$ & $\begin{array}{c}-0.001^{* * *} \\
(0.000)\end{array}$ & $\begin{array}{c}-0.001^{* * *} \\
(0.001)\end{array}$ & & \\
\hline MS & $\begin{array}{c}0.774^{* * *} \\
(0.000)\end{array}$ & $\begin{array}{c}0.825^{* * *} \\
(0.000)\end{array}$ & $\begin{array}{c}-0.028^{* * *} \\
(0.005)\end{array}$ & $\begin{array}{c}-0.032^{* * *} \\
(0.005)\end{array}$ & $\begin{array}{c}7.037^{* * *} \\
(0.000)\end{array}$ & $\begin{array}{c}6.008^{* * *} \\
(0.000)\end{array}$ \\
\hline Constant & $\begin{array}{c}1.395^{* * *} \\
(0.000)\end{array}$ & $\begin{array}{c}1.396^{* * *} \\
(0.000)\end{array}$ & $\begin{array}{l}0.016^{*} \\
(0.096)\end{array}$ & $\begin{array}{c}0.012 \\
(0.276)\end{array}$ & $\begin{array}{c}-6.043^{* * *} \\
(0.000)\end{array}$ & $\begin{array}{c}-6.088^{* * *} \\
(0.000)\end{array}$ \\
\hline Year & Control & Control & Control & Control & Control & Control \\
\hline Fixed effect & Control & Control & Control & Control & Control & Control \\
\hline Number & 20544 & 14662 & 20149 & 14369 & 20695 & 14768 \\
\hline$R^{2}$ & 0.215 & 0.220 & 0.023 & 0.025 & 0.055 & 0.058 \\
\hline F Value & $111.480^{* * *}$ & $86.650^{* * *}$ & $12.742^{* * *}$ & $9.282^{* * *}$ & $28.532^{* * *}$ & $21.827^{* * *}$ \\
\hline
\end{tabular}

The managers will take some measures to find job highlights in order to increase the salary or obtain promotion channels, even if these measures have no effect on the operation and development of the company or are not conducive to long-term development [51]. For example, blockchain can serve as a focal point for managers to grasp and comply with government policies, even if the company is not suitable for the blockchain technology, or does not give full play to the role of the blockchain, and even does not increase research or investment expenditure for the blockchain, and treat if only as a method of hype. As an important index to measure the corporate governance environment, the higher the proportion of the largest shareholder, the more the shareholder participates in the company's decisionmaking. The smaller the information asymmetry between shareholders and managers, they can identify whether managers use blockchain technology to improve the company's performance to reduce managers' blockchain adverse selection $[52,53]$. We make a group test according to the proportion of the largest shareholder, using the logit model, the results are shown in regressions (1)-(2) of Table 11, we can see that when the proportion of the largest shareholder is lower, the reverse selection problem is more serious, and while if the proportion of largest shareholder is the highest, the reverse selection problem is not obvious.

(2) Earning quality: the information asymmetry between the company and outside investors will cause the volatility of the company's stock price. When the company delivers good news, the company's stock price will rise, generating abnormal returns [54]. Blockchain is one of the most promising technologies in China. When a company discloses blockchain technology, it will attract more investors and get a good market response. Even if the company's performance is poor, blockchain is simply used as a gimmick to the hype, and investors may not understand how the companies use the blockchain. Actually, there is a cognitive bias, which can lead to blind following [55], resulting in a phenomenon of adverse selection. When the corporate information transparency is worse, the degree of information asymmetry between the company and external investors is more serious [56], the easier it is for companies to engage in adverse selection activities. We use the Jones model to estimate the degree of earning management. The absolute value of earning management measures the earning quality. We test the adverse selection behavior according to the level of earning quality by groups and use the logit model. The results are shown in regressions (3)-(4) of Table 11 . We can see that the worse the earning quality, the enterprises with poor performance are more inclined to take the behavior of adverse selection by blockchain. At the same time, the phenomenon is not obvious when the earning quality is good.

(3) State-owned property right: considering the particularity of Chinese state-owned enterprises, we test the influences of state-owned property right on the 
TABLE 11: The effect of adverse selection in a different corporate governance environment.

\begin{tabular}{|c|c|c|c|c|c|c|}
\hline & $\begin{array}{c}(1) \\
\text { Largest high }\end{array}$ & $\begin{array}{c}(2) \\
\text { Largest low }\end{array}$ & $\begin{array}{c}(3) \\
E Q \text { high }\end{array}$ & $\begin{array}{c}(4) \\
E Q \text { low }\end{array}$ & $\begin{array}{c}(5) \\
\text { State }=1\end{array}$ & $\begin{array}{c}(6) \\
\text { State }=0\end{array}$ \\
\hline$R O A$ & $\begin{array}{l}-1.269 \\
(0.257)\end{array}$ & $\begin{array}{c}-2.519^{* * *} \\
(0.001)\end{array}$ & $\begin{array}{l}-1.969 \\
(0.237)\end{array}$ & $\begin{array}{c}-2.389^{* * *} \\
(0.000)\end{array}$ & $\begin{array}{c}0.971 \\
(0.646)\end{array}$ & $\begin{array}{c}-2.297^{* * *} \\
(0.000)\end{array}$ \\
\hline Size & $\begin{array}{c}0.020 \\
(0.822)\end{array}$ & $\begin{array}{c}0.324^{* * *} \\
(0.000)\end{array}$ & $\begin{array}{c}0.109 \\
(0.151)\end{array}$ & $\begin{array}{c}0.254^{* * *} \\
(0.001)\end{array}$ & $\begin{array}{c}0.129 \\
(0.232)\end{array}$ & $\begin{array}{l}0.174^{* *} \\
(0.011)\end{array}$ \\
\hline State & $\begin{array}{l}-0.072 \\
(0.727)\end{array}$ & $\begin{array}{c}-0.776^{* * *} \\
(0.000)\end{array}$ & $\begin{array}{c}-0.329^{*} \\
(0.077)\end{array}$ & $\begin{array}{c}-0.537^{* * * *} \\
(0.005)\end{array}$ & & \\
\hline Lev & $\begin{array}{c}0.661 \\
(0.240)\end{array}$ & $\begin{array}{c}-1.756^{* * *} \\
(0.000)\end{array}$ & $\begin{array}{l}-0.703 \\
(0.176)\end{array}$ & $\begin{array}{c}-0.851^{* *} \\
(0.038)\end{array}$ & $\begin{array}{l}-0.296 \\
(0.677)\end{array}$ & $\begin{array}{c}-0.784^{*} \\
(0.054)\end{array}$ \\
\hline Largest & $\begin{array}{c}-3.222^{* * *} \\
(0.001)\end{array}$ & $\begin{array}{c}-4.836^{* * *} \\
(0.000)\end{array}$ & $\begin{array}{c}-2.145^{* * *} \\
(0.000)\end{array}$ & $\begin{array}{c}-1.946^{* * *} \\
(0.001)\end{array}$ & $\begin{array}{l}-0.480 \\
(0.565)\end{array}$ & $\begin{array}{c}-2.701^{* * *} \\
(0.000)\end{array}$ \\
\hline Firmage & $\begin{array}{l}-0.457 \\
(0.113)\end{array}$ & $\begin{array}{l}-0.397 \\
(0.222)\end{array}$ & $\begin{array}{l}-0.457 \\
(0.115)\end{array}$ & $\begin{array}{l}-0.403 \\
(0.144)\end{array}$ & $\begin{array}{l}-0.504 \\
(0.321)\end{array}$ & $\begin{array}{c}-0.411^{*} \\
(0.093)\end{array}$ \\
\hline Growth & $\begin{array}{l}-0.017 \\
(0.893)\end{array}$ & $\begin{array}{c}-0.148 \\
(0.321)\end{array}$ & $\begin{array}{l}-0.180 \\
(0.272)\end{array}$ & $\begin{array}{l}-0.047 \\
(0.677)\end{array}$ & $\begin{array}{l}-0.316 \\
(0.117)\end{array}$ & $\begin{array}{l}-0.056 \\
(0.613)\end{array}$ \\
\hline$M S$ & $\begin{array}{c}6.505 \\
(0.126)\end{array}$ & $\begin{array}{l}2.320 \\
(0.626)\end{array}$ & $\begin{array}{c}7.191 \\
(0.226)\end{array}$ & $\begin{array}{c}4.470 \\
(0.238)\end{array}$ & $\begin{array}{c}2.595 \\
(0.663)\end{array}$ & $\begin{array}{l}6.618^{*} \\
(0.092)\end{array}$ \\
\hline Constant & $\begin{array}{c}0.013 \\
(0.995)\end{array}$ & $\begin{array}{c}-6.086^{* * *} \\
(0.000)\end{array}$ & $\begin{array}{l}-1.909 \\
(0.279)\end{array}$ & $\begin{array}{c}-5.374^{* * *} \\
(0.005)\end{array}$ & $\begin{array}{l}-3.215 \\
(0.329)\end{array}$ & $\begin{array}{c}-3.498^{* *} \\
(0.023)\end{array}$ \\
\hline Year & Control & Control & Control & Control & Control & Control \\
\hline Number & 5409 & 5448 & 5321 & 5536 & 3638 & 7219 \\
\hline$R^{2}$ & 0.087 & 0.091 & 0.082 & 0.074 & 0.104 & 0.068 \\
\hline Chi Value & $158.061^{* * *}$ & $157.644^{* * *}$ & $138.134^{* * *}$ & $144.010^{* * *}$ & $91.233^{* * *}$ & $195.415^{* * *}$ \\
\hline
\end{tabular}

reverse selection. State-owned enterprises have financial support and are supervised by the government, and their future investment direction should also be decided by the state [57]. At the same time, state-owned enterprises are not only required to undertake economic goals but also social goals [58]; executive promotion and compensation incentives are not only influenced by firm performance, but the achievement of social goals by state-owned enterprises can also be a factor for executive promotion [59]. Therefore, the agency conflicts between managers and shareholders of state-owned enterprises are smaller than that of private enterprises. By contrast, private enterprises' corporate performance decline will influence the executive compensation and promotion directly. Therefore, to mitigate the negative impact of corporate performance decline and attract more investors to raise the stock price of companies, executives have incentives to use the blockchain to the hype, regardless of whether it works. We make a test in groups by state-owned enterprises and private enterprises, using the logit model, and the result is shown in regressions (5)-(6) of Table 11. It can be seen that the degree of adverse selection by private enterprises is more serious. In contrast, the degree of adverse selection by state-owned enterprises is not obvious.

This table presents the regression results across subsamples of firms sorted by different corporate governance environments. We use the logit model to test. The dependent variable is a dummy variable of whether the company uses blockchain in the current year. The independent is ROA. We divide the samples into groups according to Largest, EQ, and
State. The Largest is defined as the proportion of the largest shareholder, which can describe the company's equity structure. EQ is the earning quality, which is measured by the absolute value of earning management. State is the stateowned property right of the company. This sample is listed companies in the CSMAR database from 2016 to 2019 because there are samples of companies using blockchain since 2016. The $p$ values in parentheses are standard errors based on heteroskedasticity-consistent. The symbols ***, **, and * indicate statistical significance at the $1 \%, 5 \%$, and $10 \%$ levels, respectively.

\subsubsection{External Macroenvironment}

(1) Degree of marketability: the advantage of blockchain is that trust can be established between enterprises through computer code. In the past, enterprises may need long-term transactions to establish long-term relationships with suppliers and customers. The emergence of blockchain can help enterprises establish short-term cooperative relationships with other enterprises without long-term cooperation. In areas with a high degree of marketization, information and resources flow quickly. The local government has a sophisticated economic system to regulate, and enterprises can choose an alternative partner quickly. In contrast, in areas with weak marketization, enterprises can only choose fewer partners, and transactions can only be maintained by establishing long-term stable relationships so that the blockchain can play a better role in areas with weak marketization. Therefore, to attract trading partners and investors, enterprises in areas with weak marketization are more inclined to use 
TABLE 12: The effect of adverse selection in different external macroenvironment.

\begin{tabular}{|c|c|c|c|c|}
\hline & $\begin{array}{c}\text { (1) } \\
\text { Market high }\end{array}$ & $\begin{array}{c}(2) \\
\text { Market low }\end{array}$ & $\begin{array}{c}(3) \\
\text { Law high }\end{array}$ & $\begin{array}{c}(4) \\
\text { Law low }\end{array}$ \\
\hline$R O A$ & $\begin{array}{l}-0.848 \\
(0.384)\end{array}$ & $\begin{array}{c}-3.039^{* * *} \\
(0.000)\end{array}$ & $\begin{array}{l}-1.969 \\
(0.237)\end{array}$ & $\begin{array}{c}-2.389^{* * *} \\
(0.000)\end{array}$ \\
\hline Size & $\begin{array}{c}0.161^{*} \\
(0.063)\end{array}$ & $\begin{array}{c}0.208^{* * *} \\
(0.006)\end{array}$ & $\begin{array}{c}0.109 \\
(0.151)\end{array}$ & $\begin{array}{c}0.254^{* * *} \\
(0.001)\end{array}$ \\
\hline State & $\begin{array}{l}-0.085 \\
(0.724)\end{array}$ & $\begin{array}{c}-0.635^{* * *} \\
(0.001)\end{array}$ & $\begin{array}{c}-0.329^{*} \\
(0.077)\end{array}$ & $\begin{array}{c}-0.537^{* * *} \\
(0.005)\end{array}$ \\
\hline Lev & $\begin{array}{l}-0.250 \\
(0.691)\end{array}$ & $\begin{array}{c}-1.196^{* * *} \\
(0.006)\end{array}$ & $\begin{array}{l}-0.703 \\
(0.176)\end{array}$ & $\begin{array}{c}-0.851^{* *} \\
(0.038)\end{array}$ \\
\hline Largest & $\begin{array}{c}-2.275^{* * *} \\
(0.001)\end{array}$ & $\begin{array}{c}-1.848^{* * *} \\
(0.004)\end{array}$ & $\begin{array}{c}-2.145^{* * *} \\
(0.000)\end{array}$ & $\begin{array}{c}-1.946^{* * *} \\
(0.001)\end{array}$ \\
\hline Firmage & $\begin{array}{l}-0.492 \\
(0.142)\end{array}$ & $\begin{array}{c}-0.467^{*} \\
(0.099)\end{array}$ & $\begin{array}{l}-0.457 \\
(0.115)\end{array}$ & $\begin{array}{l}-0.403 \\
(0.144)\end{array}$ \\
\hline Growth & $\begin{array}{l}-0.043 \\
(0.751)\end{array}$ & $\begin{array}{l}-0.098 \\
(0.480)\end{array}$ & $\begin{array}{l}-0.180 \\
(0.272)\end{array}$ & $\begin{array}{l}-0.047 \\
(0.677)\end{array}$ \\
\hline$M S$ & $\begin{array}{l}9.360^{* *} \\
(0.040)\end{array}$ & $\begin{array}{c}0.408 \\
(0.926)\end{array}$ & $\begin{array}{c}7.191 \\
(0.226)\end{array}$ & $\begin{array}{c}4.470 \\
(0.238)\end{array}$ \\
\hline Constant & $\begin{array}{l}-3.310 \\
(0.117)\end{array}$ & $\begin{array}{c}-3.894^{* *} \\
(0.032)\end{array}$ & $\begin{array}{l}-1.909 \\
(0.279)\end{array}$ & $\begin{array}{c}-5.374^{* * *} \\
(0.005)\end{array}$ \\
\hline $\begin{array}{l}\text { Year } \\
\text { Number }\end{array}$ & $\begin{array}{c}\text { Control } \\
4581\end{array}$ & $\begin{array}{c}\text { Control } \\
6276\end{array}$ & $\begin{array}{c}\text { Control } \\
5321\end{array}$ & $\begin{array}{c}\text { Control } \\
5536\end{array}$ \\
\hline$R^{2}$ & 0.072 & 0.087 & 0.082 & 0.074 \\
\hline$C h i^{2}$ Value & $129.229^{* * *}$ & $188.345^{* * *}$ & $138.134^{* * *}$ & $144.010^{* * *}$ \\
\hline
\end{tabular}

blockchain to hype. This paper makes use of the China Marketization Index compiled by Wang et al. [60]. The index includes the relationship between the government and the market, the development of the non-state-owned economy, product market, factor market, intermediary market organizations, and the legal system environment. It is a good index to measure the level of market development in various regions. We carry out a grouping test according to the high and low level of marketization index, using the logit model, the results are shown in regressions (1)-(2) of Table 12, and we can see that the areas with lower marketization degree are more inclined to adverse selection by blockchain. In contrast, the adverse selection behavior is not obvious in the regions with a high degree of marketization.

(2) The law environment: blockchain is a newly developed technology, which can establish the trust relationship between enterprises. The smart contract can realize the automatic transaction by setting up the code to avoid the default of enterprises so that the blockchain can alleviate the weakness of the law environment. In areas with a good law environment, enterprises can resolve the problems through legal proceedings when disputes arise. However, in the area with a weak law environment, disputes between enterprises may be handled inefficiently, proceedings may be difficult to implement, and there may even be cases in which the courts shield powerful local enterprises, which may cause enterprises to suffer losses due to the risk of litigation; these companies have less competitiveness in the market and will have incentives to use blockchain technology to attract partners even if they do not invest in blockchain, and the weaker the environment of law, the more partners the enterprises can attract by using blockchain to hype. This paper measures the degree of law environment by using the index of judicial justice and efficiency in the report of "the Business Environment Index for Enterprises in Chinese Provinces" compiled by Wang et al. [61], we carry out a grouping test according to the high and low level of law environment, using the logit model, the results are shown in regressions (3)-(4) of Table 12, and we can see that the degree of reverse selection is higher in the area where the law environment is weak, but the phenomenon is not obvious in the area where the law environment is good.

This table presents the regression results across subsamples of firms sorted by different external macroenvironment. We use the logit model to test. The dependent variable is a dummy variable of whether the company uses blockchain in the current year, the independent is $R O A$, and we divide the samples into groups according to the variables of Market and Law. The Market is the marketability degree of the area the company is located. The index comes from China Marketization Index compiled by Wang et al. [60]. Law is the law environment of the area the company is located. The index comes from the "Business Environment Index for Enterprises in Chinese Provinces" compiled by Wang et al. [13]. We supplement the missing index of Market and Law using the existing value in the last year. This sample is listed companies in the CSMAR database from 2016 to 2019 because there are samples of companies using blockchain since 2016. The $p$ values in parentheses are standard errors 
based on heteroskedasticity-consistent. The symbols ***, ${ }^{* *}$, and ${ }^{*}$ indicate statistical significance at the $1 \%, 5 \%$, and $10 \%$ levels, respectively.

\section{Conclusions and Discussion}

Blockchain is one of the emerging technologies focusing on the prospect of the blockchain future development and the process design in the enterprise management. However, there are relatively few studies on the role and problems of blockchain in the actual operation of enterprises using empirical data. From the theoretical analysis, blockchain can reduce information transparency nand transaction costs, while improving trust between enterprises and their efficiency to enhance enterprise performance. However, we find a negative correlation between the application of blockchain and enterprise performance, which is inconsistent with the expectation of blockchain theory. We explore the deep reasons and find that the main reason for the above effect lies in the adverse selection behavior of enterprises. The application of blockchain complies with the policy of the Chinese government and future technical direction. Therefore, enterprises can use blockchain as a kind of conceptual hyping method. The companies disclosing blockchain in annual reports will earn more stock returns and increase stock turnover. Therefore, the companies with worse performance are more likely to use blockchain technology to improve their reputation and turn around their operating conditions. However, these enterprises may not be suitable to use blockchain technology or do not make full use of blockchain. They even do not increase investment and $\mathrm{R} \& \mathrm{D}$ expenditure to develop blockchain applications. Their behaviors of adverse selection are serious. In addition, the inherent operational defects of such enterprises have not been solved, and the gains from adverse selection are temporary. In the long run, the market-to-book ratio, government subsidies, and the income growth rate of such enterprises will decline. The financial constraints will not be alleviated, and the corporate performance will decrease further.

In addition, we also look for methods to alleviate the adverse selection of enterprises. From the perspectives of the internal governance environment, firstly, a higher proportion of the largest shareholder in a company can reduce the information asymmetry between managers and shareholders, which can prevent executives from using blockchain to the hype for compensation or promotion. Secondly, good earning quality can reduce the information asymmetry between the company and outside investors and alleviate the company's blockchain hype for raising stock price. Thirdly, the private enterprises pay more attention to the economic target of the company compared with state-owned enterprises, so their behaviors of reverse selection are serious. When the corporate performance is poor, they tend to relieve the economic pressure through the hype of blockchain. Investors should pay more attention to private companies using blockchain. From the perspectives of the macroeconomic environment, the blockchain can achieve trust among enterprises through computer code. The effect of blockchain is better in the areas where the degree of marketization is low. The law environment is poor, enterprises in such areas are more inclined to hype with blockchain to attract investors and partners, and the motivation of adverse selection is stronger; collaborators need to raise vigilant with these companies.

We consider that the development of China's blockchain technology is still at an early stage. Due to the government's vigorous promotion and publicity, enterprises carry out blockchain business too quickly. Some enterprises that are not suitable to use blockchain at the present stage also carry out blockchain activities to attract investors. However, the blockchain does not play its due effect, which leads to the reverse selection behavior. Only a few enterprises can take advantage of blockchain to improve their performance. However, most enterprises' performance decreases because of the unsuitable conditions. They do not reach their goals of reducing financial constraints and raising revenue growth rate. Therefore, enterprises should be more down to earth, should carry out blockchain business according to their transaction characteristics and economic strength, and do not hype blindly. In addition, because not all enterprises disclosing blockchain business can make full use of blockchain to develop their business, so investors should pay attention to the enterprises with decentralized ownership, poor earning quality, private enterprises, and the enterprises in regions with a weak degree of marketization and law environment, to avoid being confused by the blockchain hype and investing blindly.

\section{Data Availability}

The datasets used and/or analyzed during the current study are available from the corresponding author on reasonable request.

\section{Conflicts of Interest}

The authors declare that they have no conflicts of interest.

\section{Acknowledgments}

This paper was supported by the Ministry of Education, Humanities and Social Sciences project, "Study on the Evolution Path of China's Manufacturing Innovation Ecosystem under the Background of the New Era" (18YJC630151); Tianjin Education Commission Project, "The Economic Consequences and Influencing Factors of Inter-Firm Debt-Equity Swap" (2017SK070); Tianjin University of Commerce new staff start-up project, "Research on the Influence of Stakeholders on the Financial Management of Enterprises" (R161102); and Tianjin 131 Third-Level Talent Plan, Tianjin University of Commerce Natural Science Foundation Project, "Research on the Influence of Supply Chain Relationship on Trade Credit Synergies from Triad Perspective." 


\section{References}

[1] V. Martinez, M. Zhao, and C. Blujdea, "Blockchain-driven customer order management," International Journal of Operations \& Production Management, vol. 39, no. 6/7/8SI, pp. 993-1022, 2019.

[2] S. Nakamoto and A. Bitcoin, "A peer-to-peer electronic cash system," 2008, Bitcoin-URL: https://bitcoin.org/ bitcoin.pdf.

[3] H. Treiblmaier, "The impact of the blockchain on the supply chain: a theory-based research framework and a call for action," Supply Chain Management-An International Journal, vol. 23, no. 6, pp. 545-559, 2018.

[4] M. O Dair and Z. Beaven, "The networked record industry: how blockchain technology could transform the record industry," Strategic Change, vol. 26, no. 5, pp. 471-480, 2017.

[5] B. Biswas and R. Gupta, "Analysis of barriers to implement blockchain in industry and service sectors," Computers \& Industrial Engineering, vol. 136, no. 10, pp. 225-241, 2019.

[6] A. Gervais, G. O. Karame, K. Wüst et al., On the Security and Performance of Proof of Work blockchains, ACM, New York, NY, USA, 2016.

[7] K. S. Hald and A. Kinra, "How the blockchain enables and constrains supply chain performance," International Journal of Physical Distribution \& Logistics Management, vol. 49, no. 4, pp. 376-397, 2019.

[8] J. Mccallig, A. Robb, and F. Rohde, "Establishing the representational faithfulness of financial accounting information using multiparty security, network analysis and a blockchain," International Journal of Accounting Information Systems, vol. 33, no. 4, pp. 47-58, 2019.

[9] D. E. O'Leary, "Some issues in blockchain for accounting and the supply chain, with an application of distributed databases to virtual organizations," Intelligent Systems in Accounting Finance \& Management, vol. 26, no. 3, pp. 137-149, 2019.

[10] J. Schmitz and G. Leoni, "Accounting and auditing at the time of blockchain technology: a research agenda," Australian Accounting Review, vol. 29, no. 2, pp. 331-342, 2019.

[11] I. Radanovic and R. Likic, "Opportunities for use of blockchain technology in medicine," Applied Health Economics and Health Policy, vol. 16, no. 5, pp. 583-590, 2018.

[12] P. Csoka and P. J. Herings, "Decentralized clearing in financial networks," Management Science, vol. 64, no. 10, pp. 4681-4699, 2018.

[13] J. Wang, P. Wu, X. Wang et al., "The outlook of blockchain technology for construction engineering management," Frontiers of Engineering Management, vol. 4, no. 1, pp. 67-75, 2017.

[14] I. Barrutia Barreto, J. A. Urquizo Maggia, and S. Isaias Acevedo, "Cryptocurrencies and blockchain in tourism as a strategy to reduce poverty," Retos-Revista De Ciencias De La Administracion Y Economia, vol. 9, no. 18, pp. 275-290, 2019.

[15] C. Bai and J. Sarkis, "A supply chain transparency and sustainability technology appraisal model for blockchain technology," International Journal of Production Research, vol. 58, no. 7, pp. 2142-2162, 2020.

[16] F. Longo, L. Nicoletti, A. Padovano et al., "Blockchain-enabled supply chain: an experimental study," Computers \& Industrial Engineering, vol. 136, no. 10, pp. 57-69, 2019.

[17] R. Azzi, R. K. Chamoun, and M. Sokhn, "The power of a blockchain-based supply chain," Computers \& Industrial Engineering.vol. 135, no. 9, pp. 582-592, 2019.

[18] R. Cole, M. Stevenson, and J. Aitken, "Blockchain technology: implications for operations and supply chain management,"
Supply Chain Management-An International Journal, vol. 24, no. 4, pp. 469-483, 2019.

[19] H. Hasan, E. Alhadhrami, A. Aldhaheri et al., "Smart contractbased approach for efficient shipment management," Computers \& Industrial Engineering, vol. 136, no. 10, pp. 149-159, 2019.

[20] P. Kittipanya-Ngam and K. H. Tan, "A framework for food supply chain digitalization: lessons from Thailand," Production Planning \& Control, vol. 31, no. 2, pp. 158-172, 2020.

[21] M. Hamilton, "Blockchain distributed ledger technology: an introduction and focus on smart contracts," Journal of Corporate Accounting \& Finance, vol. 31, no. 2, pp. 7-12, 2020.

[22] T. Choi, "Blockchain-technology-supported platforms for diamond authentication and certification in luxury supply chains," Transportation Research Part E-Logistics and Transportation Review, vol. 128, no. 8, pp. 17-29, 2019.

[23] C. Yang, "Maritime shipping digitalization: blockchain-based technology applications, future improvements, and intention to use," Transportation Research Part E-Logistics and Transportation Review, vol. 131, no. 10, pp. 108-117, 2019.

[24] S. E. Chang, Y. Chen, and M. Lu, "Supply chain re-engineering using blockchain technology: a case of smart contract based tracking process," Technological Forecasting and Social Change, vol. 144, no. 7, pp. 1-11, 2019.

[25] S. Kurpjuweit, C. G. Schmidt, M. Klöckner et al., "Blockchain in additive manufacturing and its impact on supply chains," Journal of Business Logistics, vol. 42, no. 1, pp. 42-70, 2021.

[26] T. Carlin, "Blockchain and the journey beyond double entry," Australian Accounting Review, vol. 29, no. 2, pp. 305-311, 2019.

[27] B. S. Tan and K. Y. Low, "Blockchain as the database engine in the accounting system," Australian Accounting Review, vol. 29, no. 2, pp. 312-318, 2019.

[28] S. S. Kamble, A. Gunasekaran, and S. A. Gawankar, "Achieving sustainable performance in a data-driven agriculture supply chain: a review for research and applications," International Journal of Production Economics, vol. 219, no. 2, pp. 179-194, 2020.

[29] A. Jain and C. Jain, "Blockchain hysteria: adding "blockchain" to company's name[J]," Economics Letters, vol. 181, no. 8, pp. 178-181, 2019.

[30] A. Sheel and V. Nath, "Effect of blockchain technology adoption on supply chain adaptability, agility, alignment and performance," Management Research Review, vol. 42, no. 12, pp. 1353-1374, 2019.

[31] V. Hoxha and S. Sadiku, "Study of factors influencing the decision to adopt the blockchain technology in real estate transactions in Kosovo," Property Management, vol. 37, no. 5, pp. 684-700, 2019.

[32] X. Pan, X. Pan, M. Song et al., "Blockchain technology and enterprise operational capabilities: an empirical test," International Journal of Information Management, vol. 52, no. 6, Article ID 101946, 2020.

[33] S. Shahab and Z. Allam, "Reducing transaction costs of tradable permit schemes using Blockchain smart contracts," Growth and Change, vol. 51, no. 1, pp. 302-308, 2020.

[34] K. Al-Htaybat, K. Hutaibat, and L. von Alberti-Alhtaybat, "Global brain-reflective accounting practices Forms of intellectual capital contributing to value creation and sustainable development," Journal of Intellectual Capital, vol. 20, no. 6, pp. 733-762, 2019.

[35] D. Dhagarra, M. Goswami, P. R. S. Sarma et al., "Big data and blockchain supported conceptual model for enhanced 
healthcare coverage the Indian context," Business Process Management Journal, vol. 25, no. 7, pp. 1612-1632, 2019.

[36] D. E. O'Leary, “Configuring blockchain architectures for transaction information in blockchain consortiums: the case of accounting and supply chain systems," Intelligent Systems in Accounting Finance \& Management, vol. 24, no. 4, pp. 138-147, 2017.

[37] C. G. Schmidt and S. M. Wagner, "Blockchain and supply chain relations: a transaction cost theory perspective," Journal of Purchasing and Supply Management, vol. 25, no. 4, Article ID 100552, 2019.

[38] C. Cachin, Architecture of the Hyperledger Blockchain fabric, 2016.

[39] H. Lu and C. Weng, "Smart manufacturing technology, market maturity analysis and technology roadmap in the computer and electronic product manufacturing industry[J]," Technological Forecasting and Social Change, vol. 133, no. 8, pp. 85-94, 2018.

[40] E. Bonson and M. Bednarova, "Blockchain and its implications for accounting and auditing," Meditari Accountancy Research, vol. 27, no. 5SI, pp. 725-740, 2019.

[41] T. Choi and S. Luo, "Data quality challenges for sustainable fashion supply chain operations in emerging markets: roles of blockchain, government sponsors and environment taxes," Transportation Research Part E-Logistics and Transportation Review, vol. 131, no. 9, pp. 139-152, 2019.

[42] S. Manski, "Building the blockchain world: technological commonwealth or just more of the same?" Strategic Change, vol. 26, no. 5, pp. 511-522, 2017.

[43] J. M. Sklaroff, "Smart contracts and the cost of inflexibility," University of Pennsylvania Law Review, vol. 166, no. 1, pp. 263-303, 2017.

[44] G. W. Peters and E. Panayi, "Understanding modern banking ledgers through blockchain technologies: future of transaction processing and smart contracts on the internet of money," in Banking beyond Banks and Money, pp. 239-278, Springer, Berlin, Germany, 2016.

[45] J. Chiu and T. V. Koeppl, "Blockchain-based settlement for asset trading," Review of Financial Studies, vol. 32, no. 5, pp. 1716-1753, 2019.

[46] T. Beck, R. Levine, and A. Levkov, "Big bad banks? the winners and losers from bank deregulation in the United States," The Journal of Finance, vol. 65, no. 5, pp. 1637-1667, 2010.

[47] J. R. Emshwiller, "Follow the dotted line: first up-then down," Wall Street Journal, vol. 3, p. C1, 1999.

[48] M. A. Petersen and R. G. Rajan, "The benefits of lending relationships: evidence from small business data," The Journal of Finance, vol. 49, no. 1, pp. 3-37, 1994.

[49] G. M. Hastig and M. S. Sodhi, "Blockchain for supply chain traceability: business requirements and critical success factors," Production and Operations Management, vol. 29, no. 4, pp. 935-954, 2020.

[50] H. Wang, "A stochastic frontier analysis of financing constraints on investment: the case of financial liberalization in Taiwan," Journal of Business \& Economic Statistics, vol. 21, no. 3, pp. 406-419, 2003.

[51] M. C. Jensen and W. H. Meckling, "Theory of the firm: managerial behavior, agency costs and ownership structure," Journal of Financial Economics, vol. 3, no. 4, pp. 305-360, 1976.

[52] A. Shleifer and R. W. Vishny, "Large shareholders and corporate control," Journal of Political Economy, vol. 94, no. 3, pp. 461-488, 1986.
[53] D. Ramdani and A. van Witteloostuijn, "The shareholder-manager relationship and its impact on the likelihood of firm bribery," Journal of Business Ethics, vol. 108, no. 4, pp. 495-507, 2012.

[54] B. Zhu and F. Niu, "Investor sentiment, accounting information and stock price: evidence from China," Pacific-Basin Finance Journal, vol. 38, no. 4, pp. 125-134, 2016.

[55] P. K. Chaney and C. M. Lewis, "Earnings management and firm valuation under asymmetric information," Journal of Corporate Finance, vol. 1, no. 4, pp. 319-345, 1995.

[56] M. E. Barth, Y. Konchitchki, and W. R. Landsman, "Cost of capital and earnings transparency," Journal of Accounting and Economics, vol. 55, no. 2-3, pp. 206-224, 2013.

[57] A. Shleifer and R. W. Vishny, "Politicians and firms," The Quarterly Journal of Economics, vol. 109, no. 4, pp. 995-1025, 1994.

[58] Q. Zhu, J. Liu, and K. Lai, "Corporate social responsibility practices and performance improvement among Chinese national state-owned enterprises," International Journal of Production Economics, vol. 171, no. 8, pp. 417-426, 2016.

[59] M. Bradshaw, G. Liao, and M. S. Ma, "Agency costs and tax planning when the government is a major shareholder," Journal of Accounting and Economics, vol. 67, no. 2, pp. 255-277, 2019.

[60] X. L. Wang, G. Fan, and L. P. Hu, Marketization Index of Chinese Provinces: NERI Report 2018, Social Sciences Academic Press, Beijing, China, 2018, in Chinese.

[61] X. L. Wang, G. Fan, and G. R. Ma, Report on the Operating Environment Index of Chinese Provincial Enterprises in 2017, Social Sciences Academic Press, Beijing, China, 2017, in Chinese. 